\title{
Characterizing ozone production in the Mexico City Metropolitan Area: a case study using a chemical transport model
}

\author{
W. Lei ${ }^{1,2}$, B. de Foy ${ }^{2,3}$, M. Zavala ${ }^{1,2}$, R. Volkamer ${ }^{1,4}$, and L. T. Molina ${ }^{1,2}$ \\ ${ }^{1}$ Department of Earth, Atmospheric and Planetary Sciences, Massachusetts Institute of Technology, MA, USA \\ ${ }^{2}$ Molina Center for Energy and the Environment, CA, USA \\ ${ }^{3}$ Saint Louis University, MO, USA \\ ${ }^{4}$ Department of Chemistry and Biochemistry, University of California, San Diego, CA, USA
}

Received: 6 July 2006 - Published in Atmos. Chem. Phys. Discuss.: 17 August 2006

Revised: 17 January 2007 - Accepted: 20 February 2007 - Published: 27 February 2007

\begin{abstract}
An episodic simulation is conducted to characterize midday (12:00-17:00 CDT) ozone $\left(\mathrm{O}_{3}\right)$ photochemical production and to investigate its sensitivity to emission changes of ozone precursors in the Mexico City Metropoli$\tan$ Area (MCMA) during an "O ${ }_{3}$-South" meteorological episode using the Comprehensive Air Quality Model with extensions (CAMx). High $\mathrm{O}_{\mathrm{x}}\left(\mathrm{O}_{3}+\mathrm{NO}_{2}\right)$ photochemical production rates of $10-80 \mathrm{ppb} / \mathrm{h}$ are predicted due to the high reactivity of volatile organic compounds (VOCs) in which alkanes, alkenes, and aromatics exert comparable contributions. The predicted ozone production efficiency is between 4-10 $\mathrm{O}_{3}$ molecules per $\mathrm{NO}_{\mathrm{x}}$ molecule oxidized, and increases with VOC-to- $\mathrm{NO}_{2}$ reactivity ratio. Process apportionment analyses indicate significant outflow of pollutants such as $\mathrm{O}_{3}$ and peroxyacetyl nitrate (PAN) from the urban area to the surrounding regional environment. PAN is not in chemical-thermal equilibrium during the photochemically active periods. Sensitivity studies of $\mathrm{O}_{3}$ production suggest that $\mathrm{O}_{3}$ formation in the MCMA urban region with less chemical aging $\left(\mathrm{NO}_{\mathrm{z}} / \mathrm{NO}_{\mathrm{y}}<0.3\right)$ is VOC-limited. Both the simulated behavior of $\mathrm{O}_{3}$ production and its sensitivities to precursors suggest that midday $\mathrm{O}_{3}$ formation during this episode is VOC-sensitive in the urban region on the basis of the current emissions inventory estimates, and current $\mathrm{NO}_{\mathrm{x}}$ levels depress the $\mathrm{O}_{3}$ production.
\end{abstract}

\section{Introduction}

In recent decades, air pollution has become one of the most important and challenging problems for megacities in the world (Molina and Molina, 2004; Molina et al., 2004). Air pollution, such as high tropospheric ozone $\left(\mathrm{O}_{3}\right)$ and particulate matter (PM), has detrimental impacts on human

Correspondence to: W. Lei

(wflei@mit.edu) health and ecosystems, and can contribute significantly to climate change. In the lower troposphere, ozone is produced from photochemical reactions involving volatile organic compounds (VOCs, broadly including $\mathrm{CO}$ ) and nitrogen oxides $\left(\mathrm{NO}_{\mathrm{x}}=\mathrm{NO}+\mathrm{NO}_{2}\right)$ in the presence of sunlight. $\mathrm{O}_{3}$ concentrations can exceed health standards in polluted urban environments under favorable meteorological conditions (such as stagnation) and high anthropogenic emissions of $\mathrm{NO}_{\mathrm{x}}$ and VOCs. In some urban settings biogenic hydrocarbons can also play an important role in $\mathrm{O}_{3}$ production over regions where they contribute significantly to the total burden of emitted VOCs (Chameides et al., 1988; Kleinman et al., 2005). Tropospheric $\mathrm{O}_{3}$ is also affected by transport, dispersion, and deposition processes.

A prerequisite to an effective emission-based $\mathrm{O}_{3}$ control strategy is to understand the temporal and spatial relationship between $\mathrm{O}_{3}$ and its precursors, and the response of $\mathrm{O}_{3}$ concentrations to changes in emissions of $\mathrm{NO}_{\mathrm{x}}$ and VOCs. Furthermore, an effective $\mathrm{O}_{3}$ control strategy should include efforts to reduce $\mathrm{O}_{3}$ production rates in areas that affect peak $\mathrm{O}_{3}$ concentrations in a receptor site (Tonnesen and Denis, 2000). The ozone-precursor relationship can be better understood in terms of $\mathrm{NO}_{\mathrm{x}}$ or VOC-sensitive chemistry of $\mathrm{O}_{3}$ formation, which is usually defined based on the relative impact of a given percent reduction in $\mathrm{NO}_{\mathrm{x}}$ relative to VOCs in the context of urban chemistry (Sillman, 1999). Using this definition in this paper, the VOC-sensitive (or VOClimited) regime refers to conditions where a percent reduction in VOCs would lead to a significantly greater decrease in $\mathrm{O}_{3}$ with respect to the same percent reduction in $\mathrm{NO}_{\mathrm{x}}$, and vice versa.

Mexico City Metropolitan Area (MCMA) has emerged as one of the most polluted areas in the world over the last two decades (Molina and Molina, 2002). A fleet of over 3.5 million vehicles in the area, together with industrial, commercial and service sources, as well as residential activities, inject high emissions of $\mathrm{NO}_{\mathrm{x}}$, VOCs, and primary PM to the

Published by Copernicus GmbH on behalf of the European Geosciences Union. 
atmosphere. In addition, the MCMA is located inside an elevated basin at an altitude of $2240 \mathrm{~m}$ a.s.l. surrounded by mountain ridges on the west, south and east, with a broad opening to the north and a narrow gap to the south-southwest. The high altitude makes combustion processes less efficient, leading to enhanced VOC emissions. In addition, sunlight is more intense at the high altitude and the tropical latitude $\left(19^{\circ} 25^{\prime} \mathrm{N}\right)$ compared to low elevation, higher latitude cities. Together, these effects are more conducive to high rates of photochemical smog formation. The meteorological conditions associated with the complex topography in the Mexico basin also contribute to the high levels of air pollution (Fast and Zhong, 1998; de Foy et al., 2005). Although the air quality has improved significantly over the last decade, persistent high levels of surface $\mathrm{O}_{3}$ and PM are observed in the MCMA, and the national standards are often violated throughout the year (Molina and Molina, 2002; GDF, 2004).

Many modeling efforts on $\mathrm{O}_{3}$ photochemistry have been carried out in the MCMA in conjunction with previous field measurements conducted in the MCMA (LANL/IMP, 1994; IMP, 1998; Doran et al., 1998; Edgerton et al., 1999; Baumgardner et al., 2000; Raga et al., 2001). Jazcilevich et al. $(2002,2003)$ simulated the effects of land-use change on the pollutant concentrations. 3-D photochemical airshed models have also been applied to reproduce $\mathrm{O}_{3}$ concentrations and evaluate the emission uncertainties (Streit and Guzman, 1996; West et al., 2004). Box models have been employed to investigate the effects of emission reduction options (Streit and Guzman, 1996; Young et al., 1997). However, due to the quality of emission estimates, lack of constraints from comprehensive measurements, particularly speciated VOC measurements, and lack of accounting for transport and/or usage of averaged meteorological fields, contradictory implications for $\mathrm{O}_{3}$ control strategies were drawn. In addition, to our knowledge, there are no peer-reviewed modeling studies focusing on $\mathrm{O}_{3}$ production rates in the MCMA, and few comprehensive model studies incorporating comprehensive measurements have been conducted to investigate the combined roles of meteorology, chemistry, emissions and deposition in $\mathrm{O}_{3}$ formation, spatial distribution, and temporal evolution in the MCMA (Molina and Molina, 2002; Jazcilevich et al., 2005).

The MCMA-2003 Campaign was an integrated field measurement campaign that generated by far the most comprehensive suite of data sets for gaseous species, particles, and meteorological fields in the MCMA (Zavala et al., 2006; Volkamer et al., 2005; Shirley et al., 2006; Salcedo et al., 2006, 2007; de Foy et al., 2005; detailed information on the Campaign is also available at http://www.mce2.org). One of the goals of the Campaign was to improve the current understanding of the chemistry and transport processes and the evolution of pollutants in the MCMA atmosphere, and to provide insights for devising emission reduction strategies. The role of meteorology in air pollution in the MCMA has been relatively well characterized and analyzed through modeling efforts (de Foy et al., 2005, 2006a, b). Oxidation characteristics of VOCs have also been investigated through measurements of secondary species and/or radical species (Marley et al., 2004; Volkamer et al., 2005; Shirley et al., 2006).

In this paper, we employ a 3-D chemical transport model (CTM), the Comprehensive Air Quality Model with extensions (CAMx), to investigate $\mathrm{O}_{3}$ photochemical production in the MCMA and its response to $\mathrm{O}_{3}$ precursors under the " $\mathrm{O}_{3}$-South" meteorological conditions (de Foy et al., 2005), with the emissions of precursors particularly speciated VOCs constrained by measurements. Characteristics of $\mathrm{O}_{3}$ production under other meteorological conditions will be reported in a subsequent paper. The objectives are to characterize the $\mathrm{O}_{3}$ production rate, partition the contributions to the $\mathrm{O}_{3}$ production of processes of chemistry, physical transformation and transport, and to evaluate the sensitivity of $\mathrm{O}_{3}$ formation to emission reduction of anthropogenic VOCs and $\mathrm{NO}_{\mathrm{x}}$. Section 2 gives a brief description of the modeling methodology. Section 3 presents and discusses the modeling performance, in situ $\mathrm{O}_{3}$ photochemical production, contributions of different processes to $\mathrm{O}_{3}$ formation, and sensitivity analysis of the $\mathrm{O}_{3}$ response to emissions reduction. A summary of conclusions is provided in Sect. 4.

\section{Modeling methodology}

\subsection{Model and model inputs}

A 3-D chemical transport model, CAMx (version 4.03), is employed for this study. CAMx is an Eulerian photochemical grid model designed to investigate air quality issues on urban and regional scales (ENVIRON, 2003). CAMx simulates the emission, transport, chemistry, and deposition processes of pollutants in the troposphere.

CAMx is driven by hourly meteorological output fields from the Penn State/National Center for Atmospheric Research (PSU/NCAR) Mesoscale Modeling System (MM5) (Grell et al., 1995), including wind, temperature, water vapor, cloud/rain and land use. The vertical diffusion coefficients were deduced from the MM5 output based on the O'Brien scheme (1970), and the minimum values were set to $2-4 \mathrm{~m}^{2} / \mathrm{s}$ (day-varying) in the MCMA. De Foy et al. (2007) concluded that this was a better scheme for representing the vertical dispersion in the MCMA. MM5 was configured to three one-way nestings with grid resolutions of 36,12 and $3 \mathrm{~km}$ and 23 sigma levels in the vertical, and was run with the NOAH soil model, MRF boundary layer scheme, K-F convection scheme, simple ice microphysics, and cloud radiation scheme (de Foy et al., 2006a). The CAMx model domain is the same as the MM5 Domain 3 (D3), except that four grids were trimmed from each edge (resulting in $52 \times 52$ grid cells), with 15 vertical layers corresponding to the lowest 15 layers in the MM5, extending from the surface to $5 \mathrm{~km}$ a.g.l. with the bottom layer interface of about $64 \mathrm{~m}$ a.g.l. Figure 1 


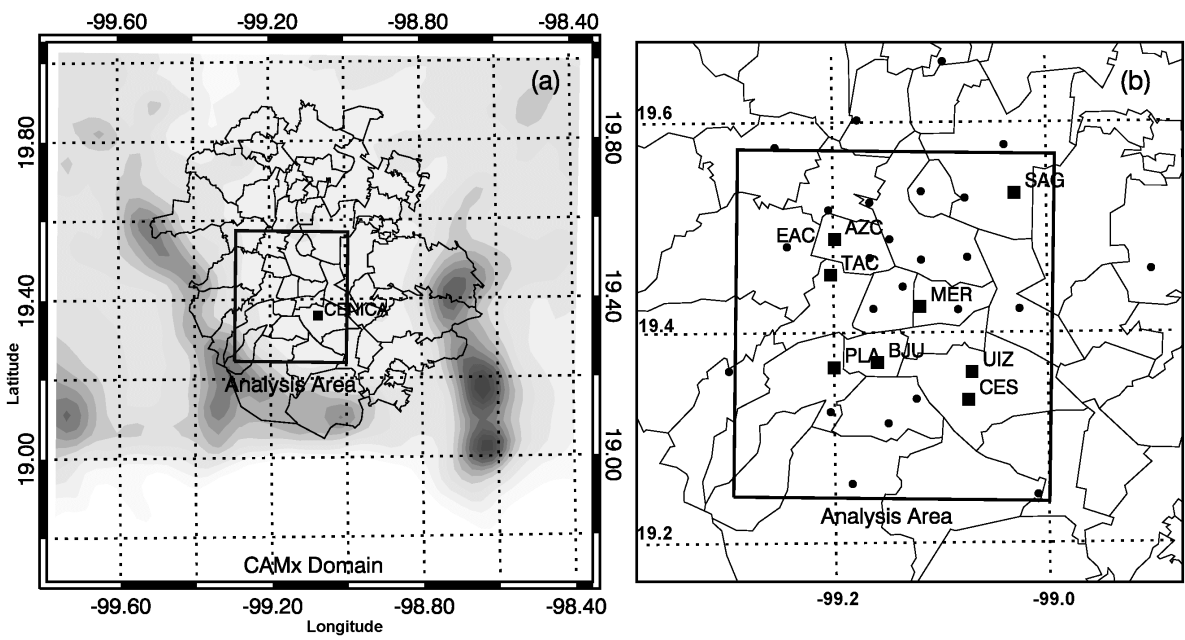

Fig. 1. (a) Model domain and (b) RAMA monitoring stations. The grey contour in (a) indicates the terrain topography. Also shown in (a) is the "urban analysis area" (the inner bold square), the central urban area where most of the RAMA monitoring stations are located. The RAMA monitoring stations are indicated as filled circles and filled squares. The 8 stations marked as filled squares with the station codes along side are denoted in the text as REP- 8 stations. The thin curves are the MCMA delegation political borderlines. The location of the MCMA-2003 Campaign supersite CENICA is also indicated in (a).

illustrates the CAMx domain; it also defines a region, designated as "urban analysis area" herein, which is located in the central urban region and contains most of the monitoring stations of the Ambient Air Monitoring Network of Mexico City (RAMA). Analyses and discussions in this study are mainly focused in this area.

The chemical initial and boundary conditions (BCs) were similar to those used in West et al. (2004), except that lower $\mathrm{NO}_{\mathrm{x}}$, VOC and $\mathrm{CO}$ values were used for the boundary conditions. The boundary conditions were carefully examined using measurements taken at the boundary sites during the MCMA-2003 Campaign. A sensitivity run with a 50\% change of the chemical BCs (which basically covered the variations of the boundary measurements for most important species) did not show significant effects on $\mathrm{O}_{3}$ and other photochemically active species.

The SAPRC99 gas phase chemical mechanism (Carter, 2000) was used in this study. Photolysis rate frequencies for clear sky were precomputed with the Tropospheric U1traviolet and Visible radiation model (TUV, Madronich and Flocke, 1998). In the computation, the aerosol loading was scaled to match those measured during the MCMA-2003. In the highly polluted area the aerosol optical depth at 340nm wavelength was set to 0.8 , comparable to the concurrent LIDAR aerosol extinction measurements (Frey et al., 2004; Simeonov et al., 2004). The effects of cloud presence on photolysis rates were taken into account by using the approach of Chang et al. (1987).

\subsection{Emission estimates}

The emission input fields were constructed based on the 2002 official emissions inventory (EI) for MCMA (CAM, 2004). Total annually emitted masses of VOCs, $\mathrm{CO}$ and $\mathrm{NO}_{\mathrm{x}}$ were distributed across mobile, point and area source categories considered in the emission inventory and were transformed into spatially and temporally resolved and chemically speciated emission fields, following the procedures described in West et al. (2004). Updated industrial, road and area sourcespecific databases were used for the construction of emission fields using a bottom-up approach. When information from area source-specific emission categories was not available, updated population-based distributions were used as proxies for spatial distributions. In addition, the spatial resolution of the emissions has been increased by mapping the updated industrial, mobile and area emissions into grid cells at a resolution of $2.25 \mathrm{~km}$. The emission input fields described above are referred to as the initial emission estimates henceforth. A summary of the total basin-wide emissions by source category and pollutant type is given in Table 1 and a map of MCMA CO, $\mathrm{NO}_{\mathrm{x}}$ and VOC emissions is shown in Fig. 2.

It has been suggested that the VOC emissions in the $1998 \mathrm{EI}$ for the MCMA were underestimated by as much as a factor of 2-3 (Molina and Molina, 2002; ArriagaColina et al., 2004; West et al., 2004). Underestimates of VOC emissions by a factor of 2 or more were also found in some U.S. cities (Sillman, 1999; Russell and Dennis, 2000). An extensive array of VOC measurements were obtained during the MCMA-2003 Campaign using a variety of techniques, including canister sampling analyzed by Gas Chromatography/Flame Ionization Detection 

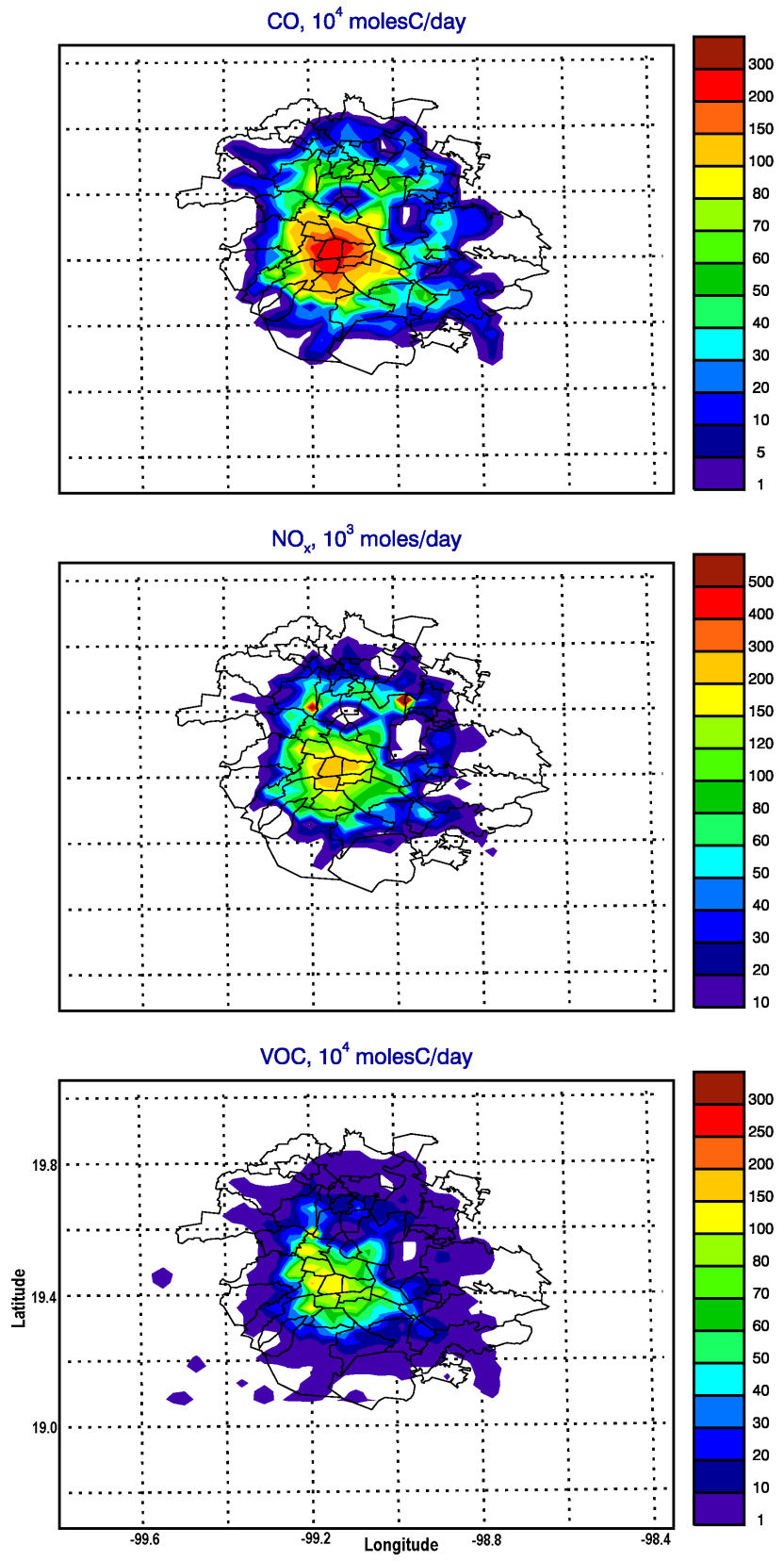

Fig. 2. Spatial distribution of $\mathrm{CO}, \mathrm{NO}_{\mathrm{x}}$ and $\mathrm{VOC}$ emissions for a normal weekday in the initial estimates from the 2002 official emission inventory.

(GC-FID), long-path Differential Optical Absorption spectroscopy (DOAS), Fourier-transform Infrared Spectroscopy (FTIR) and Proton Transfer Reaction Mass Spectroscopy (PTR-MS) (Velasco et al., 2007; Volkamer et al., 2005; Rogers et al., 2006). In this study, on the basis of the initial emission estimates, model runs were carried out and modeled VOC (as well as $\mathrm{NO}_{\mathrm{y}}$ and $\mathrm{CO}$ ) concentrations were compared with the extensive suite of VOC measurements from GC-FID and DOAS. The PTR-MS data were not used due
Table 1. Total annual emissions (in ktons/year) by source category in the MCMA from the 2002 official emission inventory.

\begin{tabular}{lllll}
\hline & $\mathrm{CO}$ & $\mathrm{NO}_{\mathrm{x}}$ & VOCs $^{\mathrm{a}}$ & $\mathrm{VOCs}^{\mathrm{b}}$ \\
\hline Mobile & 1927.1 & 156.3 & 193.8 & 332.3 \\
Area & 4.4 & 6.5 & 258.9 & 439.7 \\
Point & 6.9 & 19.5 & 75.2 & 112.8 \\
Vegetation and soil & N/A & 0.6 & 16.6 & 15.2 \\
Total & 1938.4 & 183.0 & 544.5 & 900.0 \\
\hline
\end{tabular}

${ }^{\text {a }}$ Initial estimates from MCMA 2002 EI.

b Adjusted estimates.

to the difficulty in species lumping. The initial emission estimates were then adjusted until a satisfactory agreement in the comparisons was reached (see details in Sect. 3.1 for the comparisons). Mole-based scaling factors listed in Table 2 were applied to adjust the initial emission estimates. These adjustment factors were similar to those reported by Velasco et al. (2007), who used the distribution of measured ambient concentrations from canister samples to estimate adjustments in the distribution of emissions (1998 EI) by species classes. Some factors in Table 2 are different from those given by Velasco et al., because different speciation methods were used and different base year inventories (1998 vs. 2002) were employed.

Kolb et al. (2004) and Zavala et al. (2006) suggested that vehicle emissions of formaldehyde (HCHO), which may significantly influence radical budgets and photochemistry in the MCMA (Garcia et al., 2006), may be higher in the MCMA than in some U.S. urban cities. Based on the comparison of modeled concentrations and DOAS measurements at CENICA supersite (see Sect. 3.1), emissions of $\mathrm{HCHO}$ were scaled by a factor of 9 , and a scaling factor of 4 was assumed for higher aldehydes. Both the emission rates (in the initial emission estimates) and photolysis rates of the higher aldehydes are much lower than those of $\mathrm{HCHO}$; hence their role in the photochemistry is not as significant as $\mathrm{HCHO}$ in the MCMA.

The adjusted VOC emissions are also summarized in Table 1 . The total VOC emissions increase by about $65 \%$ (mass based) after the adjustment, which is lower than the previous estimates of a factor of 2 to 3 . The adjustment also considered weekend and day-to-day emission variations. It was assumed that, based on traffic count information and an analysis of the variation of morning peak $\mathrm{CO}$ concentrations, vehicular emissions decreased by about $10 \%$ on Saturday and $30 \%$ on Sunday (Garcia et al., 2006; Salcedo et al., 2006). The modeling episode (see the section below) included part of the Easter week, in which schools were closed and residents left the city for vacation. As reported in ambient concentrations and measured fluxes (Velasco et al., 2005, 2007), emissions were reduced during the Easter week. Based on 
Table 2. Adjustment factors for correction of the 2002 MCMA emissions inventory.

\begin{tabular}{lll}
\hline Model species & Adjustment factor ${ }^{+}$(this work) & Adjustment factor ${ }^{\#}$ from Velasco et al. (2007) \\
\hline Ethane & & 2.3 (see note) \\
ALK1 & 2.0 & 3.1 (see note) \\
ALK2 & 3.0 & 0.3 (see note) \\
ALK3 & 4.0 & \\
ALK4 & 1.5 & \\
ALK5 & 0.4 & \\
ETHE & 1.0 & \\
OLE1 & 1.0 & 0.4 \\
OLE2 & 1.0 & 0.2 \\
ARO1 & 1.5 & 0.6 \\
ARO2 & 1.5 & 0.7 \\
HCHO & 9.0 & \\
CCHO and RCHO & 4.0 & \\
\hline
\end{tabular}

Different speciations of alkanes in CAMx and the work of Velasco et al. were used. ALK1 ${ }^{+}$contains ethane; ALK2 ${ }^{+}$includes propane and acetylene; $\mathrm{ALK}^{+}{ }^{+}$includes n-butane, i-butane and 2,2-dimethyl butane; ALK4 ${ }^{+}$includes i-pentane, n-pentane, cyclopentane, methylcyclopentane, 2-methyl pentane, 3-methyl pentane, 2,3-dimethyl butane and hexane; ALK5 ${ }^{+}$includes cyclohexane, 2-methyl hexane, 3methyl hexane, 2,3-dimethyl pentane, 2-methyl heptane, 4-methyl heptane, i octane, n-heptane, methylcyclohexane, 2,4-dimethyl hexane, 2,3,4-trimethyl heptane, n-octane, nonane and 1,2,4 trimethylcyclohexane. ALK1 ${ }^{\#}$ is the combination of ALK2 ${ }^{+}$, ALK3 $^{+}$and ALK4 ${ }^{+}$; $\mathrm{ALK}^{\#}{ }^{\#}$ corresponds to $\mathrm{ALK} 5^{+}$.

the RAMA CO measurements, emissions during these days were downscaled by $10 \%$ of regular days. This adjusted emission scenario is defined as the reference case in this paper.

\subsection{Episode selection}

A 4-day episode (13-16 April 2003) was chosen for this study. The simulation was started at 12 April $00 \mathrm{Z}$ allowing $24 \mathrm{~h}$ for spin-up to reduce the influence of initial conditions. We chose this period because it was an " $\mathrm{O}_{3}-$ South" episode in the MCMA (de Foy et al., 2005). During "O ${ }_{3}$-South" days, meteorological conditions are characterized by weak synoptic forcing, stagnant surface winds and clear skies, which are conductive to the occurrence of high $\mathrm{O}_{3}$ levels. The basin flow is governed by a thermally-driven northerly flow from the Mexican plateau during the day and southerly gap flow from the southeast passage in the late afternoon and early evening, which leads to the highest $\mathrm{O}_{3}$ levels in the southern part of the city (de Foy et al., 2005). In addition, The "O $\mathrm{O}_{3}$-South" episode is a typical meteorological phenomenon in the MCMA, which has been extensively studied (Williams et al., 1995; Fast and Zhong, 1998; Whiteman et al., 2000; de Foy et al., 2005).

As noted above, during the early Easter Week that started on 14 April 2003, traffic counts and pollutant levels were about $10 \%$ lower than other non-holidays weeks (Garcia et al., 2006). Although the emissions during most of the time for this episode were slightly less than non-holiday period, we believe this episode can be used to represent the normal day scenario for MCMA, given the $\mathrm{O}_{3}$ patterns that occurred.

\section{Results and discussions}

The CAMx performance during this episode studied is evaluated by comparing near surface $\mathrm{O}_{3}, \mathrm{NO}_{\mathrm{y}}$ and $\mathrm{CO}$ with RAMA data and by comparing VOC concentrations with measurements from canister samples (Velasco et al., 2007) and DOAS (Volkamer et al., 2005) at CENICA. The characteristics of $\mathrm{O}_{3}$ photochemical formation are discussed next. Finally, the $\mathrm{O}_{3}$ response to precursor emission reductions is presented.

\subsection{Model performance}

The MM5 performance for the selected period has been described by de Foy et al. (2006a, b). The main features of the Mexico basin flow are well represented by the model including the northerly flow from the Mexican plateau during the day, up-slope flows on the basin edges and the southerly gap flow from the southeast passage in the late afternoon and early evening. Weak synoptic forcing leads to surface winds that are weak and variable and particularly challenging to model. The main difference between the model and the observations is the timing of the increase in surface wind speeds and the wind shift. This affects the location of the horizontal wind convergence zone, and can have a large impact on pollutant dispersion predictions.

The model performance of CAMx is evaluated by comparing near-surface concentrations of $\mathrm{O}_{3}, \mathrm{CO}, \mathrm{NO}_{\mathrm{y}}$, and VOCs with a comprehensive suite of measurements. First, the modeled hourly concentrations of $\mathrm{O}_{3}$ in the bottom model layer are compared with the RAMA measurements. Figure 3 

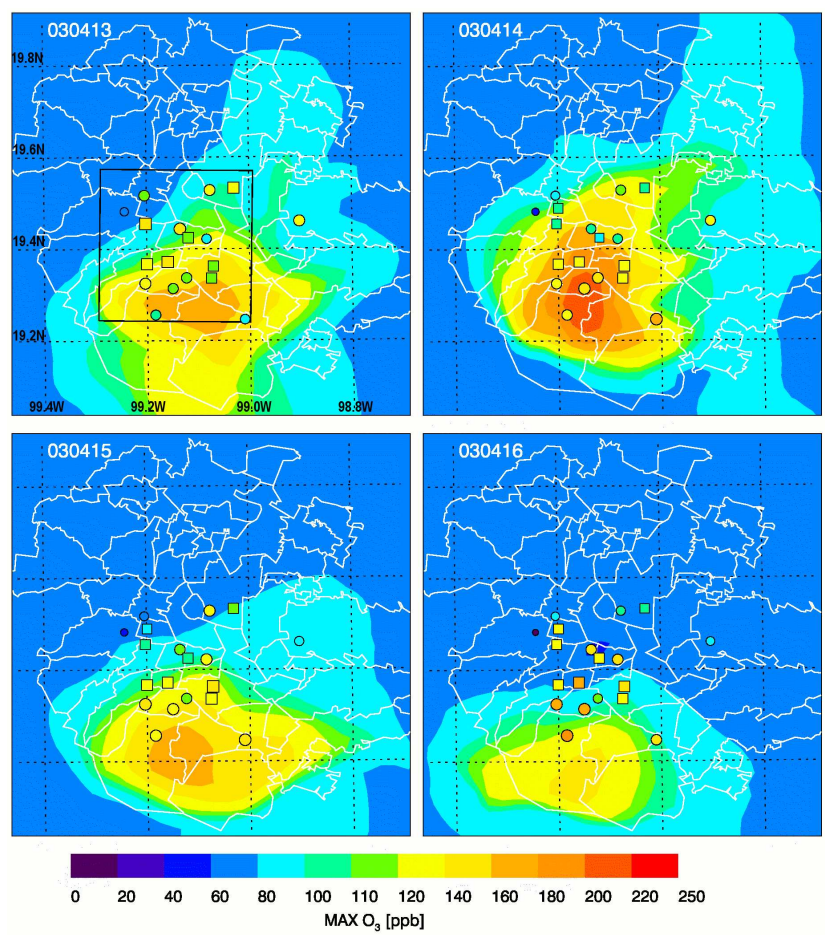

Fig. 3. Comparison of simulated (colored contour) versus observed (colored dots and squares) near-surface peak $\mathrm{O}_{3}$ concentration during 13-16 April 2003. Dots and squares indicate the positions of RAMA monitoring stations which have $\mathrm{O}_{3}$ measurements during this episode, whose size is proportional to the $\mathrm{O}_{3}$ concentration. The REP-8 stations are marked as small squares. Also shown in the upper left panel is the "urban analysis area" (encompassed by a black rectangle) in which data are used for analyses.

shows the comparison of surface peak $\mathrm{O}_{3}$ concentration and its geographic distribution. A transition from " $\mathrm{O}_{3}-\mathrm{North}$ " to "O $\mathrm{O}_{3}$-South" occurred on 13 April, with the peak $\mathrm{O}_{3}$ concentration located in a narrow strip running SW-NE through the city center. Subsequently, peak $\mathrm{O}_{3}$ concentrations occurred in the south of the city. In general, the model reproduces the spatial distribution and magnitude of peak $\mathrm{O}_{3}$ reasonably well, even though in some stations the peak $\mathrm{O}_{3}$ concentrations are off by a factor of 2 . The location of the modeled $\mathrm{O}_{3}$ center is shifted far to the south of the city, particularly on 16 April, and as a result the $\mathrm{O}_{3}$ peak levels are overestimated. On the other hand, predicted $\mathrm{NO}_{\mathrm{y}}$ concentrations (not shown) during morning rush hours are in excellent agreement with the RAMA measurements. The agreement between the predicted and observed distribution of $\mathrm{NO}_{\mathrm{y}}$ concentrations suggests that the shift of high $\mathrm{O}_{3}$ center is not due to the spatial representation of pollutant emissions.

One probable cause of the shift in the modeled $\mathrm{O}_{3}$ high concentration center (Fig. 3) is the simulated meteorological factors mentioned previously. Weak and variable surface winds can significantly influence $\mathrm{O}_{3}$ concentration and its spatial distribution on the urban scale. In addition, the dis- crepancy of simulated sharp wind shift from south-easterly to north-westerly in the morning vs. the observed gradual turning (see Fig. 15 in de Foy et al., 2006b) probably also contributes to the $\mathrm{O}_{3}$ shift. Another factor may be associated with the treatment of HONO chemistry and other missing radical sources in the SAPRC99 gas-phase chemical mechanism.

Recently both laboratory studies and field measurements have reported that the heterogeneous chemistry is a major source of nighttime HONO (Kleffmann et al., 1998; Finlayson-Pitts et al., 2003; Stutz et al., 2004), although the mechanisms at the molecular level still remain not well understood. In the current SAPRC99 mechanism, the association reaction of $\mathrm{OH}+\mathrm{NO}+\mathrm{M} \rightarrow \mathrm{HONO}+\mathrm{M}$ is the sole source of HONO in the atmosphere; it cannot explain the nighttime accumulation of HONO concentration up to a few ppb observed during the MCMA-2003 Campaign (Volkamer et al., 2007 ${ }^{1}$ ). Our simulation tests over several episodes using the reference case emissions indicated (not shown) that the model using the current SAPRC99 mechanism resulted in delayed and underpredicted radical concentrations in the high $\mathrm{NO}_{\mathrm{x}}$ MCMA area, suggesting missing radical sources or/and missing $\mathrm{NO}_{\mathrm{x}}$ sinks in the mechanism. The missing $\mathrm{HONO}$ sources and possible missing and delayed sources of other radicals can lead to the delay of $\mathrm{O}_{3}$ formation and the shift of high $\mathrm{O}_{3}$ center to the downwind regions; missing $\mathrm{NO}_{x}$ sinks can lead to overprediction of peak $\mathrm{O}_{3}$.

Two test runs with increased northerly wind flows and increasing radical concentrations (indirectly by reducing $\mathrm{NO}_{\mathrm{x}}$ emissions in the urban area), respectively, confirmed that both factors would shift the $\mathrm{O}_{3}$ high concentration center to the north, with the shift being more sensitive to the wind field change. Therefore it is likely that the shift is primarily due to meteorology, and the interactions between meteorology and missing radical sources could magnify the shift.

Figure 4 compares measured and simulated concentrations of $\mathrm{O}_{3}, \mathrm{NO}_{\mathrm{y}}$, and $\mathrm{CO}$ averaged over 8 stations within the urban area analyzed. These 8 stations (denoted as REP8 stations) represent urban conditions with less influences from nearby local emission sources. Measurements of $\mathrm{NO}_{\mathrm{x}}$ from RAMA using the chemiluminescence technique more accurately represent $\mathrm{NO}_{y}$. Accordingly, we compared the RAMA $\mathrm{NO}_{\mathrm{x}}$ data with the sum of modeled species corresponding to $\mathrm{NO}_{\mathrm{y}}$. The model using the reference emissions reproduces correctly the diurnal variation of $\mathrm{O}_{3}$ in the first 3 days, although the peak $\mathrm{O}_{3}$ on 14 April is overestimated by about $30 \mathrm{ppb}$. On the other hand, the model using the initial emissions clearly underpredicts the $\mathrm{O}_{3}$ level over the whole episode, suggesting the necessity of increasing VOC emissions. On 16 April the $\mathrm{O}_{3}$ high concentration center was

\footnotetext{
${ }^{1}$ Volkamer, R., Sheehy, P., Molina, L. T., and Molina, M. J.: Oxidative capacity of the Mexico City atmosphere. Part 1: A radical source perspective, Atmos. Chem. Phys. Discuss., to be submitted, 2007.
} 

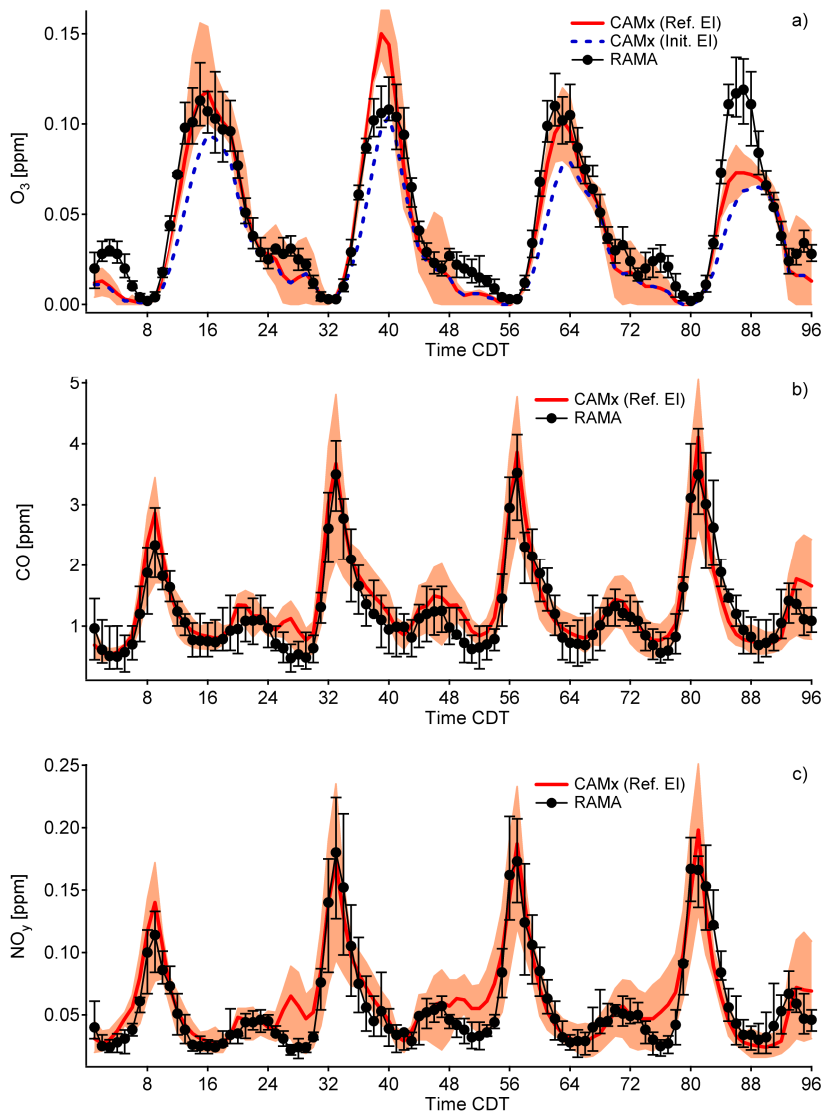

Fig. 4. Comparison of measured (black) and simulated (red) diurnal variation of near surface hourly concentrations of (a) $\mathrm{O}_{3}$, (b) $\mathrm{CO}$, and (c) $\mathrm{NO}_{\mathrm{y}}$ averaged over the REP-8 stations. Error bars and shaded areas envelop the $25 \%$ and $75 \%$ percentiles of measurements and simulations, respectively. Also shown in panel (a) is the modeled $\mathrm{O}_{3}$ time series using the initial emissions. Time in the $\mathrm{x}$-axis is the end hour in CDT (central daylight time) starting at 01:00 CDT 13 April 2003.

shifted too far to the south of the city, hence the 16 April data were not included in the analyses and discussions of photochemical characteristics of $\mathrm{O}_{3}$ formation given below.

Comparison between observed and simulated species concentrations can also provide information on the accuracy of emissions estimates. Figure 4 shows that simulated $\mathrm{CO}$ and $\mathrm{NO}_{\mathrm{y}}$ agree well with the measurements (within the modeled and experimental uncertainties), and there are no systematic biases between modeled and observed daytime $\mathrm{CO}$ and $\mathrm{NO}_{\mathrm{y}}$. Nevertheless, there appear to be some hangovers of simulated $\mathrm{CO}$ and $\mathrm{NO}_{\mathrm{y}}$ during midnight and very early morning. Most of the hangover can be explained by the underprediction of nighttime vertical mixing and planetary boundary layer (PBL) height. The larger $\mathrm{NO}_{\mathrm{y}}$ hangover is due to the relative higher nighttime $\mathrm{NO}_{\mathrm{x}}$ emission fractions (compared to $\mathrm{CO}$ ). This gives us confidence in model performance and in the accuracy of the emissions of $\mathrm{CO}$ and $\mathrm{NO}_{\mathrm{x}}$ used in the model.

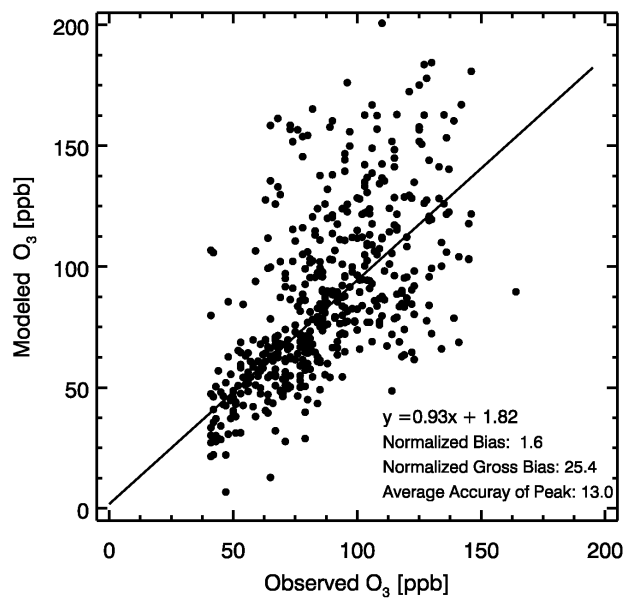

Fig. 5. Scatter plot of observed and simulated near surface $\mathrm{O}_{3}$ concentrations over all RAMA stations during 13-15 April 2003 when observed $\mathrm{O}_{3}$ values are above $40 \mathrm{ppb}$. Also shown are the linear fitting parameters and performance statistics.

Figure 5 shows the relationship between measured and predicted surface $\mathrm{O}_{3}$ concentrations over all RAMA stations during this episode, with the cutoff value set to $50 \mathrm{ppb}$ of measured concentrations. As indicated in the figure, there is good agreement between the measured and the predicted $\mathrm{O}_{3}$ concentrations. Figure 5 also presents some ozone performance statistics, such as the normalized bias (the percentage difference between the predicted and observed $\mathrm{O}_{3}$ concentrations paired in time and site with observed values above a $40 \mathrm{ppb}$ threshold), the normalized gross bias (the percentage of the absolute difference between the predicted and observed $\mathrm{O}_{3}$ concentrations paired in time and site with observed values above the threshold), and the average accuracy of the peak (the percentage difference between the predicted and observed peak $\mathrm{O}_{3}$ concentrations paired in site). These statistical values also indicate a satisfactory performance in the $\mathrm{O}_{3}$ simulation.

Finally we compare predicted VOC species with a comprehensive array of available observations described in detail in Velasco et al. (2007) and Volkamer et al. (2005). As shown in Fig. 6 (panels a-e), the predicted concentrations of alkenes and speciated alkanes agree very well with measured concentrations (30-min average) from canister samples (Velasco et al., 2007). Figure 6 also shows the comparison of predicted concentrations of aromatics and formaldehyde with those measured by DOAS. Observed ARO1 (Fig. 6f) was constructed from DOAS measurements of toluene and benzene, and observed ARO2 (Fig. 6g) was derived from DOAS measurements of xylenes using a scaling factor obtained from the canister data in which the contribution of xylenes to ARO2 can be estimated. There is good agreement between modeled and measured concentrations for aromatics on 14-15 April, and no systematic bias exists. The measured 


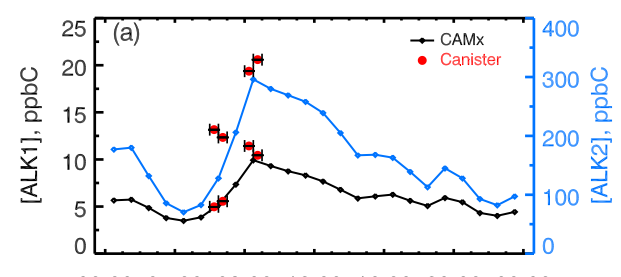

00:00 04:00 08:00 12:00 16:00 20:00 00:00

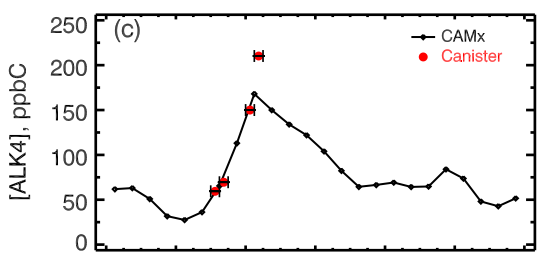

00:00 04:00 08:00 12:00 16:00 20:00 00:00

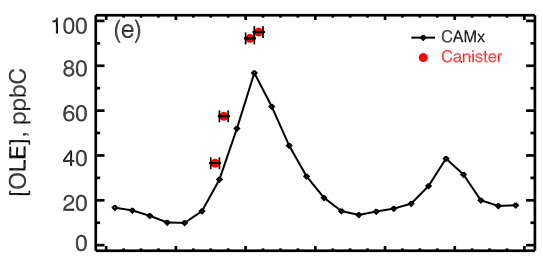

00:00 04:00 08:00 12:00 16:00 20:00 00:00 $4 / 14$, CDT

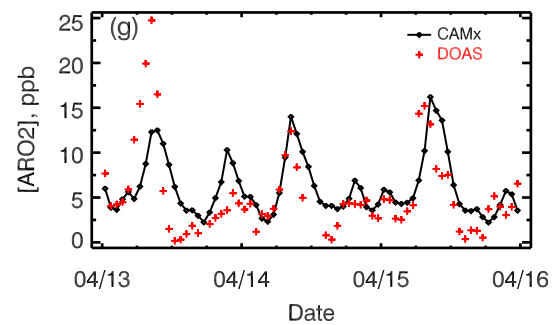

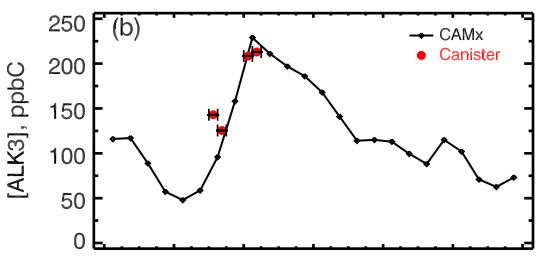

00:00 04:00 08:00 12:00 16:00 20:00 00:00

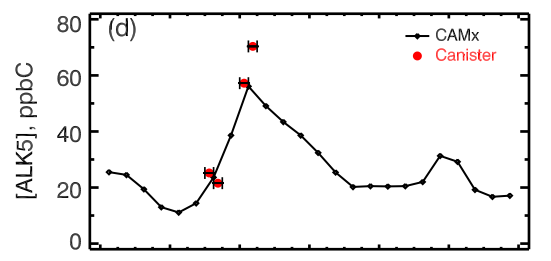

00:00 04:00 08:00 12:00 16:00 20:00 00:00
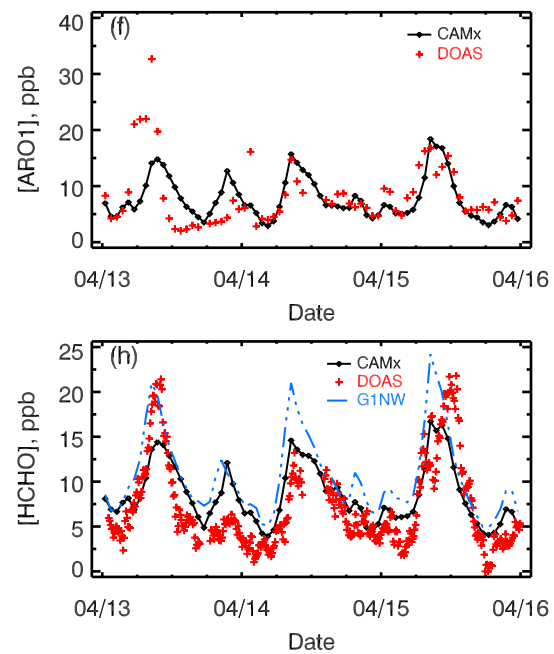

Fig. 6. Comparisons of modeled VOC concentrations with canister and DOAS measurements at CENICA supersite. Canister data are 30-min averages. The legend G1NW denotes one model grid northwest of CENICA ( $3 \mathrm{~km}$ north and west respectively).

aromatic concentrations on 13 April are much higher than the rest of the measurement period, which the model is unable to reproduce. However, the phenomenon of much higher predicted aromatic concentrations on 13 April compared to other days is not found in the case of $\mathrm{CO}, \mathrm{NO}_{\mathrm{x}}$ or $\mathrm{HCHO}$. $\mathrm{HCHO}$ is somewhat underestimated during the morning hours at CENICA site even with an adjustment factor of 9 to the HCHO emissions. Nevertheless, grid cells a few kilometers north and west of CENICA were predicted to have much higher $\mathrm{HCHO}$ concentrations. Figure 6h shows the simulated $\mathrm{HCHO}$ concentrations at the model grid $3 \mathrm{~km}$ northwest of CENICA (dashed line), which gives similar peak HCHO concentrations as the DOAS observations at CENICA. This may suggest an uncertainty in the spatial distribution of HCHO in the EI: CENICA site is located at the edge of high vehicular emission area in the current emission estimates; the total emission estimates may need to be allocated over a broader area, considering the growth of the city.

Based on these comparisons, it seems that emissions of some VOC species are underestimated by a factor of 2-3 in the EI, but not all VOCs are underestimated. Overall the emissions of VOCs are underestimated by about $65 \%$. This result is consistent with the conclusions from Velasco et al. (2007), which are based on comparisons of 1998 EI with canister data of early morning VOC abundance over several sampling sites. It should be noted, however, that the adjustments of VOC emissions in this study were solely based on comparisons at only one station (CENICA), over a few days (one day for alkanes and alkenes), with limited dataset, and with assumptions that the spatial and temporal distribution of emissions in the EI were accurate. To thoroughly evaluate the uncertainty of EI, more measurement data and investigations with broader spatial and temporal coverage are needed. 
Table 3. Notation.

\begin{tabular}{|c|c|}
\hline Symbol & Meaning \\
\hline $\mathrm{P}_{G}$ & Gross chemical production rate \\
\hline $\mathrm{P}$ & Net chemical production rate \\
\hline $\mathrm{L}$ & Chemical loss rate \\
\hline Q & Radical primary sources \\
\hline PFR & Peroxide formation rate \\
\hline $\mathrm{L}_{R}$ & Radical loss rate due to radical-radical reactions of $\mathrm{OH}+\mathrm{HO}_{2}$ and $\mathrm{RO}_{2}+\mathrm{R}^{\prime} \mathrm{O}_{2}$ \\
\hline$L_{N}$ & Radical loss rate due to reactions between free radicals and $\mathrm{NO}_{\mathrm{x}}$ \\
\hline$L_{O N}$ & $\begin{array}{l}\text { Formation rate of PANs, other organic nitrates, and particulate nitrates. Difference between this term } \\
\text { and } L_{N} \text { is that the latter includes the } \mathrm{HNO}_{3} \text { formation rate from the } \mathrm{OH}+\mathrm{NO}_{2} \text { reaction }\end{array}$ \\
\hline$k_{t}$ & Weighted average rate constant for reaction of $\mathrm{HO}_{2}$ and $\mathrm{RO}_{2}$ with $\mathrm{NO}$ \\
\hline$k_{\text {eff }}$ & Effective rate constant for peroxide $\left(\mathrm{H}_{2} \mathrm{O}_{2}+\mathrm{ROOH}\right)$ formation \\
\hline$k_{\mathrm{OH}}-\mathrm{VOC}$ & Rate constant for reaction of $\mathrm{VOC}+\mathrm{OH}$ \\
\hline$k_{\mathrm{OH}-\mathrm{NO}_{2}}$ & Rate constant for reaction of $\mathrm{NO}_{2}+\mathrm{OH}$ \\
\hline$K_{\text {VOC }}$ & $\begin{array}{l}\text { VOC reactivity, defined as the product of the VOC concentration and the rate constant for the reaction } \\
\text { of } \mathrm{VOC}+\mathrm{OH}\end{array}$ \\
\hline$K_{\mathrm{NO} 2}$ & $\begin{array}{l}\mathrm{NO}_{2} \text { reactivity, defined as the product of the } \mathrm{NO}_{2} \text { concentration and the rate constant for the reaction of } \\
\mathrm{NO}_{2}+\mathrm{OH}\end{array}$ \\
\hline OPE & Ozone production efficiency, defined as $\mathrm{P}\left(\mathrm{O}_{3}\right) / \mathrm{P}\left(\mathrm{NO}_{\mathrm{z}}\right)$ \\
\hline$Y$ & Average yield of $\left[\mathrm{HO}_{2}\right]+\left[\mathrm{RO}_{2}\right]$ for each $\mathrm{OH}+\mathrm{VOC}$ reaction \\
\hline
\end{tabular}

3.2 Photochemical formation rate and production efficiency

\subsubsection{Theoretical background}

$\mathrm{O}_{3}$ formation can be considered a radical competition process in which VOCs and $\mathrm{NO}_{\mathrm{x}}$ compete for the $\mathrm{OH}$ radical (Seinfeld and Pandis, 1998). When $\mathrm{NO}_{\mathrm{x}}$ increases and passes the turnaround level, defined as the $\mathrm{NO}_{\mathrm{x}}$ concentration at which $\mathrm{O}_{3}$ production rate $\mathrm{P}\left(\mathrm{O}_{3}\right)$ reaches a maximum, $\mathrm{P}\left(\mathrm{O}_{3}\right)$ is expected to decrease. Based on the concept of radical budget $\left(\mathrm{OH}+\mathrm{HO}_{2}+\mathrm{RO}_{2}\right)$, Sillman et al. (1990), Kleinman et al. (1997), and Daum et al. (2000) derived analytical solutions for $\mathrm{O}_{3}$ photochemical production in terms of $\mathrm{O}_{3}$ precursors and other oxidation products that can be readily measured. These analytical equations have been widely used in box models to calculate $\mathrm{O}_{3}$ production rates based on observations.

$$
\begin{aligned}
& P_{G}\left(\mathrm{O}_{3}\right)=\frac{k_{t}}{\sqrt{2 k_{\mathrm{eff}}}} \sqrt{Q-L_{N}-L_{R}}[\mathrm{NO}] \\
& P_{G}\left(\mathrm{O}_{3}\right)=Y \frac{k_{\mathrm{OH}-\mathrm{VOC}[\mathrm{VOC}]}}{k_{\mathrm{OH}-\mathrm{NO}_{2}\left[\mathrm{NO}_{2}\right]}}\left(Q-2 \mathrm{PFR}-L_{R}-L_{O N}\right),
\end{aligned}
$$$$
\text { VOC-limited }
$$

Notations used in these equations and the rest of this paper are listed in Table 3. Note that $\mathrm{Q}$ is the production rate of primary radicals (i.e., radicals generated from the radical initiation, not those participating in the radical propagation. The primary radicals are not necessarily associated with direct emissions), which is determined largely by the photolysis of $\mathrm{O}_{3}$, aldehydes and other intermediate VOCs including those from VOC oxidations and direct emitters.

Equation (1) assumes that the $\mathrm{O}_{3}$ production rate is the rate of $\mathrm{NO}$ oxidation to $\mathrm{NO}_{2}$ by peroxy radicals. Thus, Eq. (1) is more suitable for examining the behavior of $\mathrm{O}_{3}$ production at low $\mathrm{NO}_{\mathrm{x}}$ concentrations (i.e., $\mathrm{NO}_{\mathrm{x}}$-limited). Equation (2) assumes that the $\mathrm{O}_{3}$ production rate can be approximated by the rate at which $\mathrm{OH}$ reacts with VOCs (i.e., VOC limited). Equation (2) is thus more appropriate for examining the behavior of $\mathrm{O}_{3}$ production at $\mathrm{NO}_{\mathrm{x}}$-abundant conditions. An implicit assumption in deriving Eq. (2) is that no primary peroxy radicals contribute to the $\mathrm{O}_{3}$ production (the $\mathrm{Q}$ term is introduced into Eq. (2) because of the need to represent $[\mathrm{OH}]$ using other species on the basis of radical budget).

Subtracting the $\mathrm{O}_{3}$ chemical loss term from $\mathrm{P}_{G}\left(\mathrm{O}_{3}\right)$ gives the net $\mathrm{O}_{3}$ chemical formation rate $\mathrm{P}\left(\mathrm{O}_{3}\right)$. Under urban conditions the $\mathrm{O}_{3}$ chemical loss term is usually much smaller than the gross production term. For example, simulations of several different episodes in the MCMA indicated that near surface $\mathrm{O}_{3}$ chemical loss was constantly about 7-9\% of the gross chemical formation in the afternoon. Therefore, Eqs. (1-2) are also good approximations for $\mathrm{P}\left(\mathrm{O}_{3}\right)$. Under low $\mathrm{NO}_{\mathrm{x}}$ conditions, $L_{N}$ and $L_{R}$ terms are negligible; while under VOC-limited conditions, $P F R$ and $L_{R}$ terms are very small compared to other radical loss pathways such as formations of $\mathrm{HNO}_{3}$, PANs and other organic nitrates (c.f. Fig. $8 \mathrm{f}$ below). Thus, Eqs. (1) and (2) can be further simplified as

$P_{G}\left(\mathrm{O}_{3}\right)=\frac{k_{t}}{\sqrt{2 k_{\mathrm{eff}}}} \sqrt{Q}[\mathrm{NO}], \mathrm{NO}_{\mathrm{x}}$-limited 


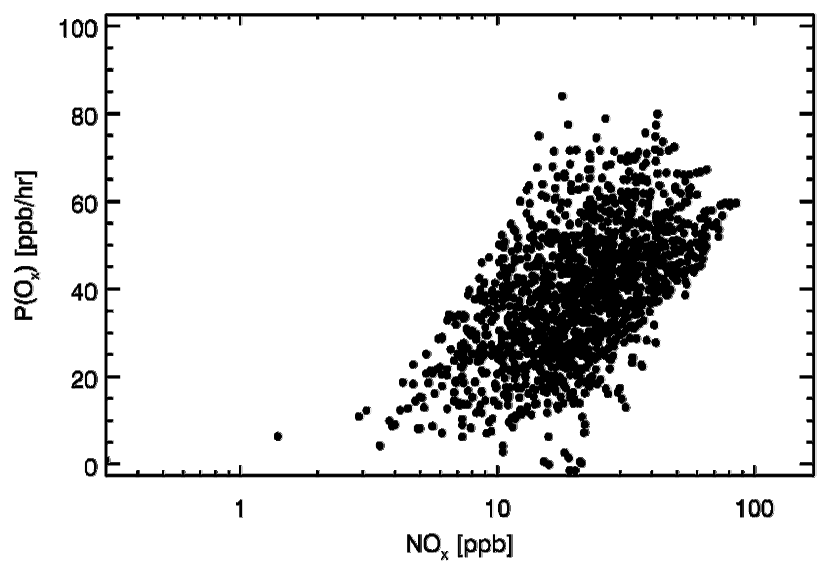

Fig. 7. Simulated dependence of photochemical production rates of $\mathrm{O}_{\mathrm{x}}\left(\mathrm{P}\left(\mathrm{O}_{\mathrm{x}}\right)\right)$ on $\mathrm{NO}_{\mathrm{x}}$ in the model bottom layer over the urban region during 12:00-17:00 CDT, 13-15 April 2003.

$$
P_{G}\left(\mathrm{O}_{3}\right)=Y \frac{k_{\mathrm{OH}-\mathrm{VOC}}[\mathrm{VOC}]}{k_{\mathrm{OH}-\mathrm{NO} 2}\left[\mathrm{NO}_{2}\right]}\left(Q-L_{O N}\right), \text { VOC-limited }
$$

The rather simple forms of Eqs. (3) and (4) are a practical reason for using Eq. (1) under $\mathrm{NO}_{\mathrm{x}}$-limted conditions and Eq. (2) under VOC-limited conditions. These equations will be employed to discuss the $\mathrm{P}\left(\mathrm{O}_{3}\right)$ in the MCMA in the following section.

\subsubsection{Characteristics of ozone production rate}

We examined the net photochemical formation rates of $\mathrm{O}_{\mathrm{x}}$ $\left(\mathrm{O}_{\mathrm{x}}=\mathrm{O}_{3}+\mathrm{NO}_{2}\right.$ in this paper), $\mathrm{P}\left(\mathrm{O}_{\mathrm{x}}\right)$, as a function of $\mathrm{NO}_{\mathrm{x}}$; the results are presented in Fig. 7. $\mathrm{O}_{\mathrm{x}}$ is used here instead of $\mathrm{O}_{3}$ because $\mathrm{O}_{\mathrm{x}}$ is a more conservative quantity than $\mathrm{O}_{3}$ in that it is not influenced by the titration process of $\mathrm{NO}+\mathrm{O}_{3} \rightarrow \mathrm{NO}_{2}$. In Fig. 7, hourly-cumulative modeled data of $\mathrm{P}\left(\mathrm{O}_{\mathrm{x}}\right)$ sampled within the "urban analysis area" (c.f. Fig. 1) between 12:0017:00 CDT during 13-15 April are used. The time window of 12:00-17:00 CDT is when the most active $\mathrm{O}_{3}$ production and the $\mathrm{O}_{3}$ peak occur; thus we are in a better position to evaluate the sensitivity of $\mathrm{O}_{3}$ formation to $\mathrm{VOC}$ and $\mathrm{NO}_{\mathrm{x}}$ during the afternoon hours. In the calculation $\mathrm{P}\left(\mathrm{O}_{\mathrm{x}}\right)$ includes chemical losses of $\mathrm{NO}_{\mathrm{x}}$ to gaseous $\mathrm{HNO}_{3}$, PANs and other organic nitrates. $\mathrm{P}\left(\mathrm{O}_{\mathrm{x}}\right)$ is a good approximation for $\mathrm{P}\left(\mathrm{O}_{3}\right)$ because $\mathrm{P}\left(\mathrm{NO}_{2}\right)$ is expected to be small compared to $\mathrm{P}\left(\mathrm{O}_{3}\right)$ due to the rapid inter-conversion between $\mathrm{NO}$ and $\mathrm{NO}_{2}$ in this time window. A distinct feature in Fig. 7 is the large scattered relationship between $\mathrm{P}\left(\mathrm{O}_{\mathrm{x}}\right)$ and $\mathrm{NO}_{\mathrm{x}}$. As near-surface $\mathrm{NO}_{\mathrm{x}}$ concentrations vary between 10 and $80 \mathrm{ppb}, \mathrm{P}\left(\mathrm{O}_{\mathrm{x}}\right)$ values vary between 10 and $80 \mathrm{ppb} / \mathrm{h}$. The modeled values and the scatter in the dependence of $\mathrm{P}\left(\mathrm{O}_{\mathrm{x}}\right)$ on $\mathrm{NO}_{\mathrm{x}}$ is consistent with observation-based estimates of $\mathrm{P}\left(\mathrm{O}_{3}\right)$ (Shirley et al., 2006). Despite the scattered relationship, $\mathrm{P}\left(\mathrm{O}_{\mathrm{x}}\right)$ generally increases with $\mathrm{NO}_{\mathrm{x}}$ in the MCMA urban area, and no obvious turnaround behavior of $\mathrm{P}\left(\mathrm{O}_{\mathrm{x}}\right)$ can be deduced from Fig. 7, even when $\mathrm{NO}_{\mathrm{x}}$ concentration reaches as high as $100 \mathrm{ppb}$. The mean values of $\mathrm{P}\left(\mathrm{O}_{\mathrm{x}}\right)$ at each $\mathrm{NO}_{\mathrm{x}}$ level are much higher than in most U.S. urban regions (Kleinman et al., 2005), even at very high $\mathrm{NO}_{\mathrm{x}}$ levels, and are close to or higher than those found in the Houston metropolitan area (Kleinman et al., 2002; Lei et al., 2004).

Figure 8 shows the simulated relationship among $\mathrm{P}\left(\mathrm{O}_{\mathrm{x}}\right)$, primary radical source $(\mathrm{Q}$, in units of $\mathrm{ppb} / \mathrm{h})$, and VOCto- $\mathrm{NO}_{2}$ reactivity in the urban area analyzed. $\mathrm{P}\left(\mathrm{O}_{\mathrm{x}}\right)$ is nearly a linear function of the primary radical production rate (Fig. 8c), indicating that $\mathrm{P}\left(\mathrm{O}_{\mathrm{x}}\right)$ is predominantly determined by the availability of primary radicals. Therefore the scatter in the relationship shown in Fig. 7 reflects the dependence of the radical source on $\mathrm{NO}_{\mathrm{x}} \cdot \mathrm{P}\left(\mathrm{O}_{\mathrm{x}}\right)$ is weakly dependent on $\sqrt{Q-L_{N}}$ [NO] (Fig. 8a), suggesting that Eq. (1) can not explain the $\mathrm{P}\left(\mathrm{O}_{\mathrm{x}}\right)$ behavior in the MCMA, i.e., $\mathrm{O}_{\mathrm{x}}$ production is not $\mathrm{NO}_{\mathrm{x}}$-limited in the urban area. Instead, Eq. (4) explains the $\mathrm{P}\left(\mathrm{O}_{\mathrm{x}}\right)$ behavior well (Fig. 8d) suggesting that $\mathrm{P}\left(\mathrm{O}_{\mathrm{x}}\right)$ is largely determined by the radical source and the VOC- $\mathrm{NO}_{2}$ reactivity ratio. This implies that $\mathrm{O}_{\mathrm{x}}$ formation is VOC-limited. About $18 \%$ of the sampled data points deviate from the linear cluster, probably due to the exclusion of the contribution of primary peroxy radical sources to the $\mathrm{O}_{3}$ production in Eq. (4). HCHO has been quantified as an important radical source in the MCMA (Volkamer et al., 2007 ${ }^{1}$ ). The primary peroxy radicals may have significantly influenced a small portion of the data in Fig. 8. Including the contribution of primary peroxy radicals to $\mathrm{O}_{3}$ production would increase $\mathrm{P}\left(\mathrm{O}_{\mathrm{x}}\right)$, and thus improve the "clustering" in Fig. 8d. The slope in Fig. 8d shows that on average two peroxy radicals are yielded for each $\mathrm{OH}+\mathrm{VOC}$ reaction. We also note that $\mathrm{P}\left(\mathrm{O}_{\mathrm{x}}\right)$ is affected significantly by the $\mathrm{L}_{O N}$ term, suggesting the importance of the formation of PANs and other organic nitrates in the ozone photochemical production. The VOC-to- $\mathrm{NO}_{\mathrm{x}}$ reactivity ratio contributes to the magnitude of $\mathrm{P}\left(\mathrm{O}_{\mathrm{x}}\right)$, but there is no apparent dependency between the reactivity ratio and $\mathrm{P}\left(\mathrm{O}_{\mathrm{x}}\right)$ (Fig. 8b). The relative constant ratio of VOC-to- $\mathrm{NO}_{\mathrm{x}}$ reactivity $(\sim 3-7)$ suggests the co-emissions of $\mathrm{NO}_{\mathrm{x}}$ and VOCs in the MCMA urban area. In addition, the radical source increases with VOC reactivity (Fig. 8e). Based on Eq. (4), the relationship revealed in Figs. $8 \mathrm{~b}$ and e explains the observation that $\mathrm{P}\left(\mathrm{O}_{\mathrm{x}}\right)$ does not decrease at high $\mathrm{NO}_{\mathrm{x}}$ (Fig. 7). Figures 8c, $\mathrm{d}$ and e indicate that VOC reactivity plays an essential role in the $\mathrm{O}_{\mathrm{x}}$ photochemical production. During this period, over $90 \%$ of the radicals are lost to the $\mathrm{NO}_{\mathrm{x}}$ oxidation while less than $10 \%$ are lost to the radicalradical reactions (Fig. 8f), implying again that the $\mathrm{O}_{\mathrm{x}}$ formation is VOC-limited (Sillman et al., 1995; Kleinman et al., 1997).

In summary, during the photochemical active period of 12:00-17:00 CDT, $\mathrm{P}\left(\mathrm{O}_{\mathrm{x}}\right)$ depends not only on $\mathrm{NO}_{\mathrm{x}}$, but also on VOC reactivity and primary radical sources; $\mathrm{NO}_{\mathrm{x}}$ losses to PANs and other organic nitrates also affect $\mathrm{P}\left(\mathrm{O}_{\mathrm{x}}\right)$. There exists a scattered yet positive relationship between $\mathrm{P}\left(\mathrm{O}_{\mathrm{x}}\right)$ and $\mathrm{NO}_{\mathrm{x}}$. The dependence of $\mathrm{P}\left(\mathrm{O}_{\mathrm{x}}\right)$ on precursors is controlled by the primary radical source, which in turn is dependent 

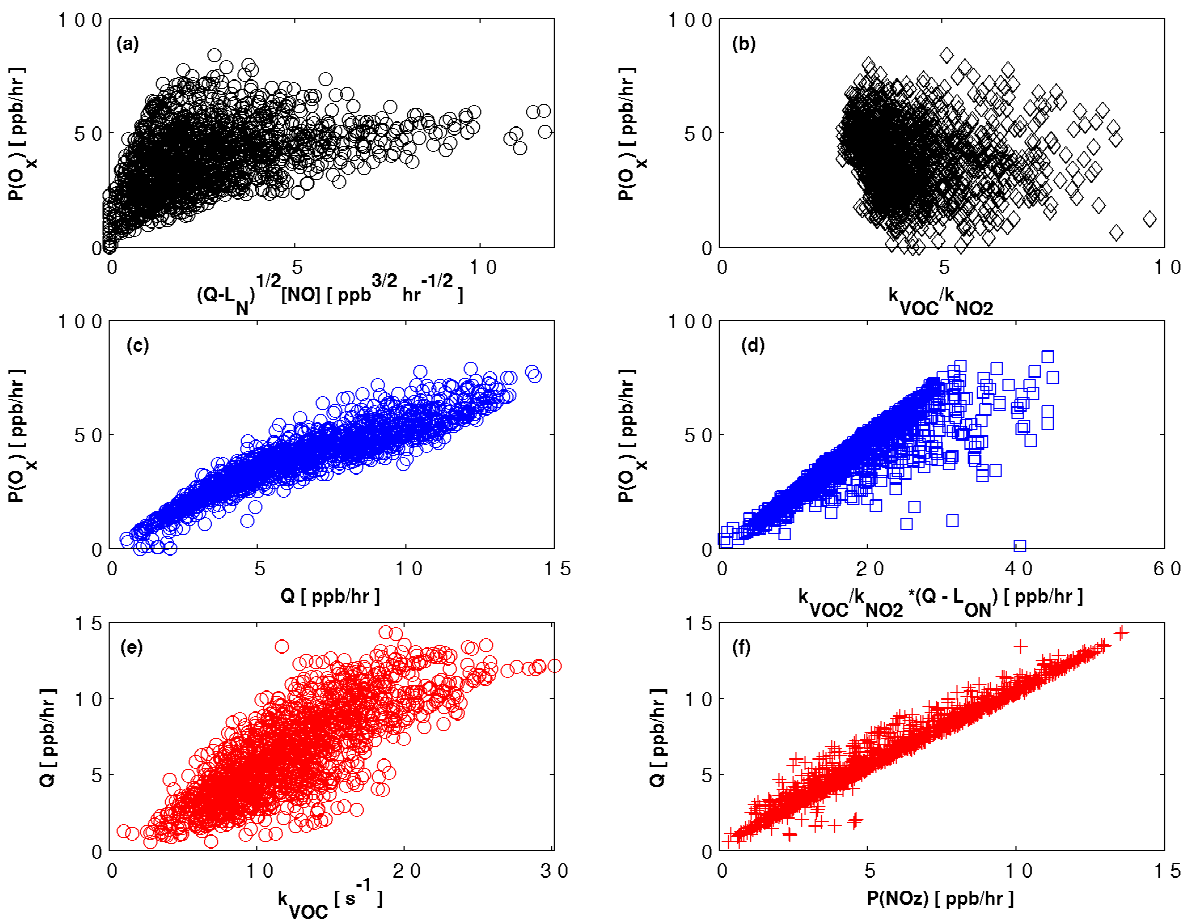

Fig. 8. Simulated relationships among $\mathrm{O}_{\mathrm{x}}$ formation rate $\left(\mathrm{P}\left(\mathrm{O}_{\mathrm{x}}\right)\right)$, primary radical source $(\mathrm{Q})$, and ratio of $\mathrm{VOC}$-to-NO 2 reactivity $\left(\mathrm{k}_{\mathrm{VOC}} / \mathrm{k}_{\mathrm{NO} 2}\right)$, and relationship between radical source as a function and VOC reactivity. Data in the "urban analysis area" between 12:0017:00 CDT 13-15 April 2003 are used.

on the VOC reactivity. The relationship between $\mathrm{P}\left(\mathrm{O}_{\mathrm{x}}\right)$ and precursors and the primary radical source suggests that $\mathrm{O}_{3}$ formation in the urban region is VOC-limited during this period.

\subsubsection{VOC reactivity partitioning}

As demonstrated above, VOC reactivity plays an essential role in determining the $\mathrm{O}_{\mathrm{x}}$ photochemical formation. Many concepts have been developed to quantify the impact of VOC reactivity (Chameides et al., 1992; Carter, 1994; Seinfeld and Pandis, 1998). In this paper we use the summation of the product of speciated VOCs and their reaction rates with $\mathrm{OH}$ because it is closely related to the discussions above and we focus on the near-field photochemistry. An effort is made to examine the apportionment of VOC reactivity. Figure 9 illustrates the contributions of various VOCs to the VOC reactivity in the afternoon. The calculated total VOC reactivity is very high with mean value $>20 \mathrm{~s}^{-1}$, which is close to the values observed in industrial plumes over the Houston Ship Channel area (Kleinman et al., 2002; Daum et al., 2003), and much higher than other U.S. urban environments (Kleinman et al., 2002, 2005; Lei et al., 2004). Including the contribution from $\mathrm{CO}$, the total reactivity (about $25 \mathrm{~s}^{-1}$ ) is in very good agreement with the $\mathrm{OH}$ reactivity observed by Shirley et al. (2006), which also includes $\mathrm{OH}$ loss to other chemical processes, e.g., $\mathrm{OH}+\mathrm{NO}_{2}$, for the same time window.

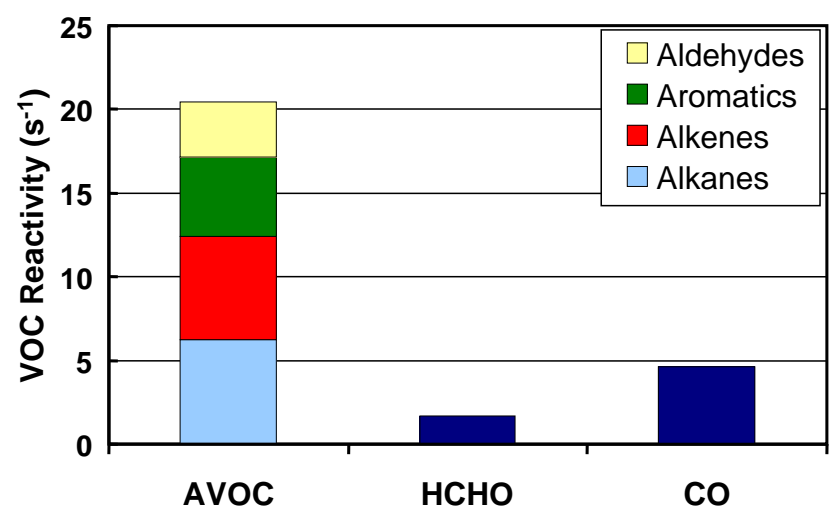

Fig. 9. Simulated VOC reactivity averaged over the "urban analysis area" during 12:00-17:00 CDT 13-15 April 2003 at model bottom layer. $\mathrm{AVOC}=$ anthropogenic VOCs. Aldehydes include HCHO.

Alkanes, alkenes and aromatics contribute comparably to the VOC reactivity, with alkanes slightly dominating. Velasco et al. (2007) reported that during the early morning rush hour, alkenes dominate the total VOC reactivity in the MCMA. As time evolves, relatively less contribution to the VOC reactivity would be expected from the more reactive alkenes in the afternoon due to their shorter lifetimes.

An important feature shown in Fig. 9 is the significant contribution from aromatics to the VOC reactivity. Aromatic 


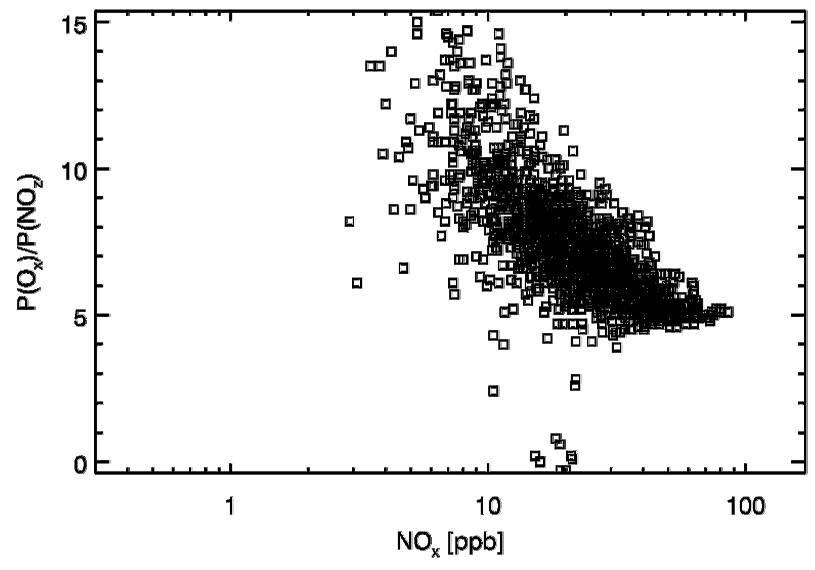

Fig. 10. Simulated relationship between ozone production efficiency $\left(\mathrm{P}\left(\mathrm{O}_{\mathrm{x}}\right)\right) / \mathrm{P}\left(\left(\mathrm{NO}_{\mathrm{Z}}\right)\right)$ and $\mathrm{NO}_{\mathrm{x}}$ at 12:00-17:00 CDT during 1315 April 2003 in the model bottom layer over the "urban analysis area".

compounds with high reactivity, such as xylenes, account for about $75 \%$ of the aromatic activity (not shown). This is unique compared to most of the urban cities in the U.S., where either alkanes or alkenes contribute the majority of VOC reactivity. Aromatics are important precursors for secondary organic aerosols (Odum et al., 1996; Seinfeld and Pandis, 1998). The importance of aromatics to the VOC reactivity may have important implications in formulating effective control strategies for the VOC-limited area, because reduction in aromatic emissions may lead to significant decrease in both $\mathrm{O}_{3}$ and organic aerosols, and hence reducing the emissions of aromatics may help to bring non-attainment areas into compliance with the national standards for $\mathrm{O}_{3}$ and PM. Aldehydes, mainly the intermediate oxidation products of primary VOCs during the sampling time window, also contribute significantly to the VOC reactivity, furthering the $\mathrm{O}_{3}$ production potentials of primary VOCs. Another noticeable feature is the role of $\mathrm{CO}$ in the $\mathrm{OH}$ reactivity due to the very high $\mathrm{CO}$ concentrations observed in MCMA.

\subsubsection{Characteristics of ozone production efficiency}

Ozone production efficiency (OPE) is defined here as the number of $\mathrm{O}_{3}$ molecules generated photochemically per $\mathrm{NO}_{\mathrm{x}}$ molecule oxidized (i.e., $\mathrm{P}\left(\mathrm{O}_{3}\right) / \mathrm{P}\left(\mathrm{NO}_{\mathrm{z}}\right) . \mathrm{NO}_{\mathrm{z}}$ is the oxidation products of $\left.\mathrm{NO}_{\mathrm{x}}\left(\mathrm{NO}_{\mathrm{z}}=\mathrm{NO}_{\mathrm{y}}-\mathrm{NO}_{\mathrm{x}}\right)\right)$. OPE is an important metric for understanding $\mathrm{O}_{3}$ formation and response to precursor emissions control because it contains information about the conditions under which $\mathrm{O}_{3}$ is produced and it is important in evaluating impacts from $\mathrm{NO}_{\mathrm{x}}$ emission sources. OPE determines the efficiency of the catalyst $\mathrm{NO}_{\mathrm{x}}$ in the $\mathrm{O}_{3}$ formation. In this study, OPE is approximated as $\mathrm{P}\left(\mathrm{O}_{\mathrm{x}}\right) / \mathrm{P}\left(\mathrm{NO}_{\mathrm{Z}}\right)$. Under conditions where the $\mathrm{O}_{3}$ titration does not significantly affect the $\mathrm{O}_{3}$ production, such an approximation is valid. Figure 10 presents the predicted afternoon hourly near surface OPE as a function of $\mathrm{NO}_{\mathrm{x}}$ in the MCMA urban area. In the calculation of $\mathrm{NO}_{\mathrm{x}}$ oxidation rate, $\mathrm{P}\left(\mathrm{NO}_{\mathrm{z}}\right)$, $\mathrm{HNO}_{3}$ formation from the reaction of $\mathrm{OH}+\mathrm{NO}_{2}$ and net formation of organic nitrates (including PANs), the predominant terms, are included; no other minor terms such as deposition and particulate $\mathrm{NO}_{3}^{-}$heterogeneous removal are considered. The calculated values of OPE frequently concentrate on 4-12 molecules of $\mathrm{O}_{3}$ per $\mathrm{NO}_{\mathrm{x}}$ oxidized at $\mathrm{NO}_{\mathrm{x}}>10 \mathrm{ppb}$, which are higher than those observed or modeled in urban plumes of most U.S. urban cities in the same $\mathrm{NO}_{\mathrm{x}}$ range, such as New York City (3-4) (Kleinman et al., 2000); Nashville (36) (St. John et al., 1998; Nunnermacker et al., 1998), Phoenix (3-5) (Kleinman et al., 2002), and Houston (3-8) (Kleinman et al, 2003; Lei et al., 2004), particularly at higher $\mathrm{NO}_{\mathrm{x}}$ levels. As shown in Eq. (2) (divided by Q, note that $Q \approx P\left(\mathrm{NO}_{\mathrm{z}}\right)$, see Fig. 8f), the OPE values are closely related to the VOC-to- $\mathrm{NO}_{2}$ reactivity ratio, and OPE increases with increasing ratio. A nonlinear dependence of OPE on $\mathrm{NO}_{\mathrm{x}}$ is also exhibited, as found by Liu et al. (1987).

\subsection{Process apportioning of ozone production in the bound- ary layer}

$\mathrm{O}_{3}$ production is the result of the interaction of the emission, chemistry, transport and deposition processes. 3-D CTMs are probably the most powerful tool to gain an integrated understanding of these interacting processes. The Process Analysis (PA) tool in CAMx is employed to apportion the $\mathrm{O}_{3}$ production from these processes. Figure 11a presents the time series of contributions of these processes to $\mathrm{O}_{3}$ production in the MCMA urban region in the boundary layer. The nighttime mixing layer height was assumed to be $500 \mathrm{~m}$ deep, close to the upper limit of observations (Frey at al., 2004). In general, positive $\mathrm{P}\left(\mathrm{O}_{3}\right)$ (net $\mathrm{O}_{3}$ photochemical production)starts at 09:00-10:00 CDT, rises significantly after 11 CDT and rapidly reaches maximum during 11:00-14:00 CDT. As the ozone production reaches a maximum, $\mathrm{O}_{3}$ is transported to the free troposphere via vertical advection; on 15 April it is also transported to the surrounding environment through the bilateral advection. The outflow of ozone to the free troposphere is accompanied by inflow through the horizontal advection to preserve the mass conservation of the air mass. The outflow of urban pollution suggests a regional-scale air quality impact. Another interesting phenomenon is that during morning hours there are little entrainments of $\mathrm{O}_{3}$ from the top of PBL.

Both the booming time (at which $\mathrm{P}\left(\mathrm{O}_{3}\right)$ rises significantly) and peak time of $\mathrm{P}\left(\mathrm{O}_{3}\right)$ are about $1 \mathrm{~h}$ earlier than that for $\mathrm{O}_{3}$ concentration itself, but are about 1-2h later than the observation-based model results from Shirley et al. (2006). Although there are many factors contributing to this discrepancy, such as the difference in height (PBL vs. surface) and geographical coverage (urban area average vs. one site), the determining factor is probably due to the missing radical sources at high $\mathrm{NO}_{\mathrm{x}}$ conditions in the chemical 
Hourly $\mathrm{O}_{3}$ change from different processes in MCMA

Grid cells used from grid $(19,22)$ to $(29,34)$ in the PBL

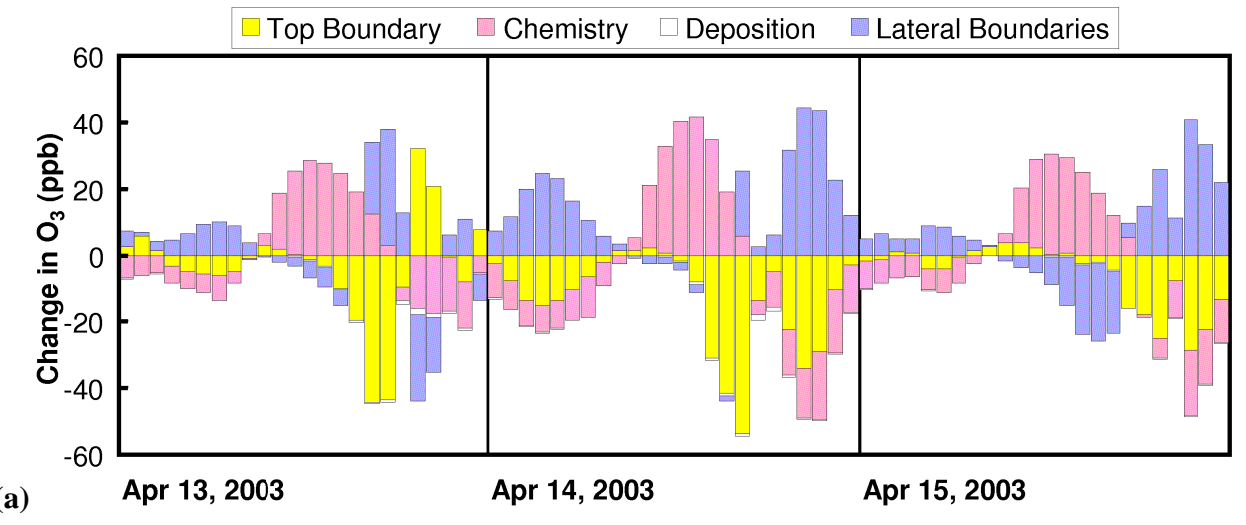

Hourly PAN change from different processes in MCMA Grid cells used from grid $(19,22)$ to $(29,34)$ in the PBL

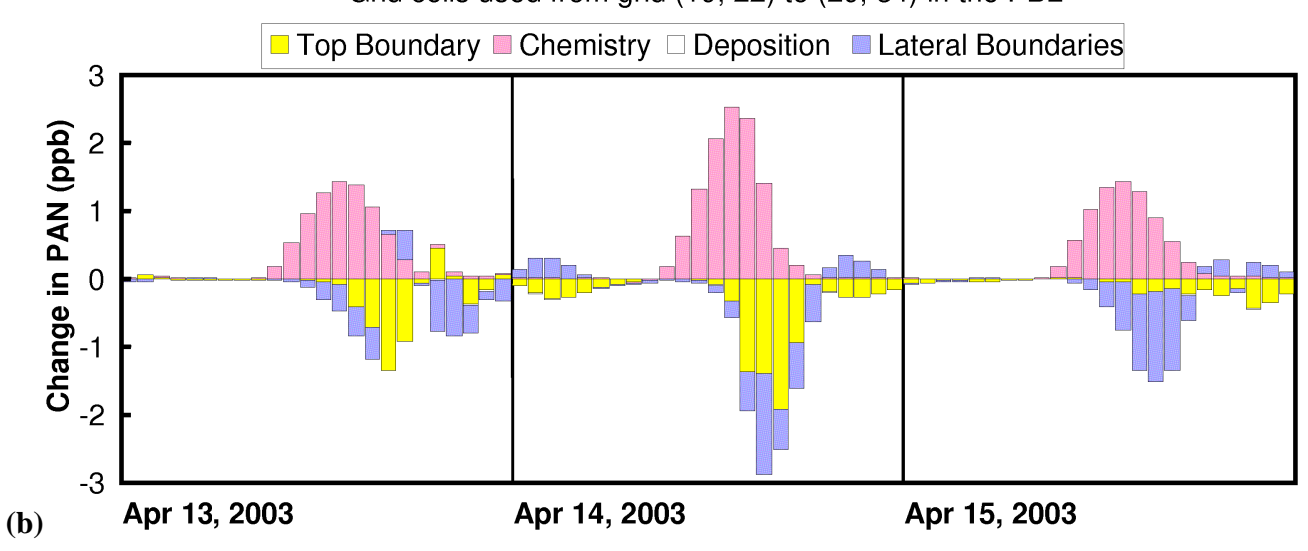

Fig. 11. Stacked time series of contribution of various processes to (a) $\mathrm{O}_{3}$ production, and (b) PAN production in the simulated boundary layer. The analysis region is confined to the "urban analysis area", and bars are the hourly-integrated production rate change due to different processes within the PBL (each bar represents one-hour data).

mechanism employed in the model as discussed previously. Carter (2005) suggests that the current oxidation mechanism for aromatics (an important VOC species in the MCMA, see Fig. 9) in SAPRC99 underpredicts radical inputs, which leads to the underprediction of $\mathrm{O}_{3}$ formation in the VOClimited environments.

Dry deposition can be important for $\mathrm{O}_{3}$ removal in the near-surface area (reaching $\sim 7 \mathrm{ppb} / \mathrm{h}$ on the diurnal average basis), but its effect is negligible for the entire PBL.

We also conduct a similar analysis for PAN, which can be an important reservoir species for $\mathrm{NO}_{\mathrm{x}}$ and radicals in lesspolluted tropospheric regions. The partitioning results are presented in Fig. 11b, which reveals two important features. First, PAN is not in chemical-thermal equilibrium during the photochemically active period. This is demonstrated by the positive net chemical/thermal production of PAN throughout the daytime period, with a production rate as high as $2 \mathrm{ppb} / \mathrm{hr}$ occurring in the mixing layer. This is contrary to the results from many urban environments. Gaffney et al. (1999) reported very high PAN concentrations in MCMA during the 1997 IMADA Campaign, which they attributed to the high levels of PAN precursors. The non-equilibrium state of PAN may also contribute to the high PAN levels. Second, significant amounts of PAN are transported to regional ambient air. This again suggests that outflows of pollutants in the MCMA may affect the ambient air quality and photochemistry on a regional scale. We expect that significant amounts of pollutants and primary pollutant precursors will be transported out of the city to the regional environments.

\subsection{Sensitivity of $\mathrm{O}_{3}$ formation to precursors}

High levels of ozone are produced in the urban areas due to anthropogenic emissions of $\mathrm{NO}_{\mathrm{x}}$ and anthropogenic and biogenic emissions of VOCs. A key issue in developing an effective $\mathrm{O}_{3}$ control strategy is to understand the nonlinear relationship between $\mathrm{O}_{3}$ formation and its precursors. In this 


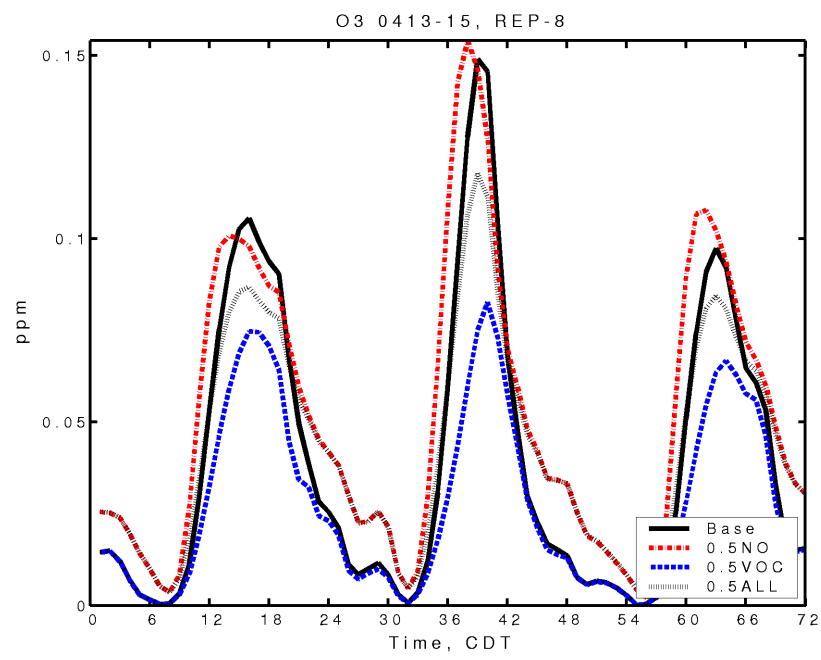

Fig. 12. Time series of $\mathrm{O}_{3}$ concentrations for different emission control scenarios. Data are averaged over the REP-8 stations in the bottom model layer. Time starts at 00:00 CDT 13 April 2003. In the legend Base denotes the reference case, $0.5 \mathrm{NO}$ denotes a $50 \%$ reduction in $\mathrm{NO}_{\mathrm{x}}$ emissions, $0.5 \mathrm{VOC}$ denotes a $50 \%$ reduction in VOC emissions, and ALL denotes a $50 \%$ reduction in emissions of both $\mathrm{NO}_{\mathrm{x}}$ and VOCs.

section we evaluate the response of $\mathrm{O}_{3}$ levels to the $\mathrm{O}_{3}$ precursors by perturbing the emission rates and examining the resulting changes in $\mathrm{O}_{3}$ concentrations and $\mathrm{O}_{3}$ photochemical production rates. The perturbations of emissions include a $50 \%$ reduction in $\mathrm{NO}_{\mathrm{x}}$ emissions, a $50 \%$ reduction in $\mathrm{VOC}$ emissions, and a $50 \%$ reduction in both $\mathrm{NO}_{\mathrm{x}}$ and VOCs emissions.

Figure 12 illustrates the effects of emissions reductions on near-surface $\mathrm{O}_{3}$ averaged over the REP- 8 stations. It clearly shows that a $50 \%$ reduction in $\mathrm{NO}_{\mathrm{x}}$ emissions leads to little decrease in $\mathrm{O}_{3}$ (on 13 April), or even increases in $\mathrm{O}_{3}$ (on 1415 April), while a 50\% reduction in VOC emissions results in decrease of $\mathrm{O}_{3}$ by nearly a factor of two. $50 \%$ reductions in both $\mathrm{NO}_{\mathrm{x}}$ and VOCs emissions also lead to a decrease in $\mathrm{O}_{3}$, but less than the VOC-only scenario. Emission reductions also affect the timing of $\mathrm{O}_{3}$ formation: the reduction in $\mathrm{NO}_{\mathrm{x}}$ emissions causes the peak $\mathrm{O}_{3}$ to form one hour earlier and the morning-hour $\mathrm{O}_{3}$ to rise more rapidly and efficiently; the reduction in VOC emissions leads to a one-hour delay in the timing of peak $\mathrm{O}_{3}$ and delays the rise in the morninghour $\mathrm{O}_{3}$. The accelerated and enhanced $\mathrm{O}_{3}$ formation in the $\mathrm{NO}_{\mathrm{x}}$-reduction case (with respect to the reference case) on 14-15 April is indicative of the $\mathrm{O}_{3}$ VOC-sensitive chemistry in the midday during this period and the depression of $\mathrm{O}_{3}$ formation under current $\mathrm{NO}_{\mathrm{x}}$ level. The $\mathrm{NO}_{\mathrm{x}}$-reduction case also indicates that $\mathrm{O}_{3}$ sensitivity evolves during the day. For example, on 14 April, with the reduction of $\mathrm{NO}_{\mathrm{x}}$ emissions, $\mathrm{O}_{3}$ increases in the morning while it decreases in the late afternoon and increases again in the evening. This concurs with the findings of Molina et al. (2002), in which detailed

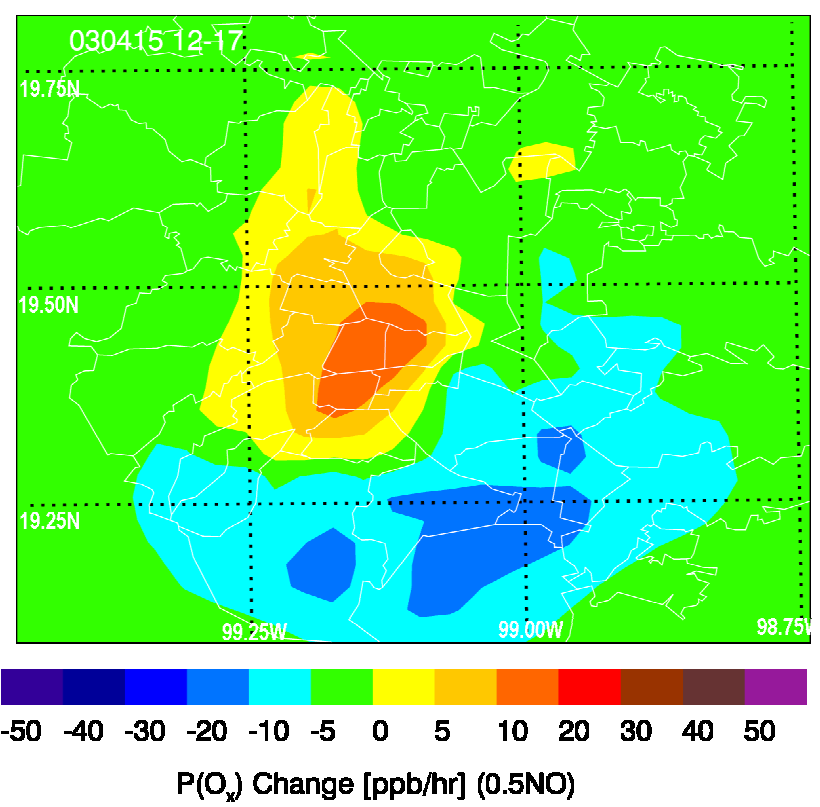

Fig. 13. Geographic distribution of changes in $\mathrm{O}_{\mathrm{x}}$ photochemical production rate in the model bottom layer on 15 April 2003 due to a 50\% reduction in $\mathrm{NO}_{\mathrm{x}}$ emissions. Data are averaged over 12:00 17:00 CDT. The change is calculated as $\mathrm{P}\left(\mathrm{O}_{\mathrm{x}}\right)$ (emission control run) $-\mathrm{P}\left(\mathrm{O}_{\mathrm{X}}\right)$ (reference run).

analyses of the evolution of $\mathrm{O}_{3}$ sensitivity to precursors were presented.

The geographic distributions of the changes of $\mathrm{P}\left(\mathrm{O}_{\mathrm{x}}\right)$, averaged over 12:00-17:00 p.m., due to a 50\% reduction in $\mathrm{NO}_{\mathrm{x}}$ emissions on 15 April 2003 are shown in Fig. 13. $\mathrm{P}\left(\mathrm{O}_{\mathrm{x}}\right)$ is used over $\mathrm{O}_{3}$ because $\mathrm{P}\left(\mathrm{O}_{\mathrm{x}}\right)$ represents instantaneous ozone chemistry that would apply to a broad range of atmospheric conditions and is less dependent on assumptions on individual calculations (Sillman, 1999). The reduction of $\mathrm{NO}_{\mathrm{x}}$ emissions leads to increases of $\mathrm{P}\left(\mathrm{O}_{\mathrm{x}}\right)$ in most of the urban area, particularly in the southern urban area, where peak $\mathrm{O}_{3}$ increases more than $20 \mathrm{ppb}$ (not shown). This suggests that $\mathrm{O}_{3}$ formation is VOC-limited during this episode in most of the MCMA urban area, which is consistent with the conclusion from the $\mathrm{P}\left(\mathrm{O}_{\mathrm{x}}\right)$ analyses in Sect. 3.2.2.

As shown in Fig. 13, the area where the ozone formation enhances most due to the $50 \%$ reduction in $\mathrm{NO}_{\mathrm{x}}$ emission is not located in the high $\mathrm{O}_{3}$ center (c.f. Fig. 3 lower left panel), but is shifted to the north of the $\mathrm{O}_{3}$ center (i.e., closer to the source region than $\mathrm{O}_{3}$ does). This suggests that the ozone formation has been depressed by the high $\mathrm{NO}_{\mathrm{x}}$ concentration in the reference case on 15 April (also on 14 April, see Fig. 12) in this area, which is consistent with the accelerated and enhanced $\mathrm{O}_{3}$ formation shown in Fig. 12. Figure 14 shows the predicted distribution of $\mathrm{NO}_{\mathrm{z}} / \mathrm{NO}_{\mathrm{y}}$ ratio in the reference case averaged from 12:00 to 17:00 CDT on 15 April for the modeled bottom layer. The ratio of $\mathrm{NO}_{\mathrm{z}} / \mathrm{NO}_{\mathrm{y}}$ reflects the chemical aging of an air plume: a chemically aged 


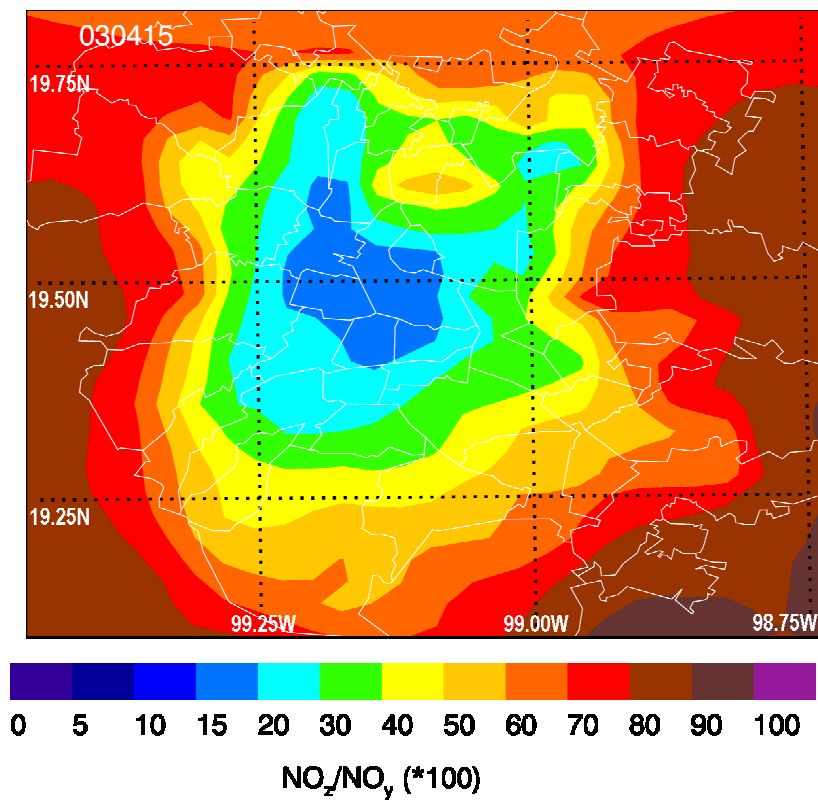

Fig. 14. Simulated geographic distribution of $\mathrm{NO}_{\mathrm{z}} / \mathrm{NO}_{\mathrm{y}}$ ratio in the reference run averaged over 12:00-17:00 CDT on 15 April 2003 in the model bottom layer.

plume possesses higher $\mathrm{NO}_{z} / \mathrm{NO}_{\mathrm{y}}$ ratios and vice-versa. Values of $\mathrm{NO}_{\mathrm{z}} / \mathrm{NO}_{\mathrm{y}}$ are also affected by advection and dispersion, deposition, and the reactive inhomogeneity of different VOCs. Figures 13 and 14 indicate that the VOC-sensitive area in the city generally coincides with the area of lower $\mathrm{NO}_{\mathrm{z}} / \mathrm{NO}_{\mathrm{y}}$ ratios; the VOC-sensitive area matches well with areas having $\mathrm{NO}_{\mathrm{z}} / \mathrm{NO}_{\mathrm{y}}$ ratios less than 0.3 . This characteristic also holds for areas of increasing $\mathrm{P}\left(\mathrm{O}_{\mathrm{x}}\right)$ with decreasing $\mathrm{NO}_{\mathrm{x}}$ emissions on 13-14 April . The area where $\mathrm{O}_{3}$ poses the largest increase due to the $\mathrm{NO}_{\mathrm{x}}$-only emissions reduction (not shown, but similar to Fig. 14 with a larger positive area) is also shifted to the north. This phenomenon may also suggest that photochemical aging plays an important role in affecting the $\mathrm{NO}_{\mathrm{x}}-\mathrm{VOC}$ sensitivity of ozone formation. In a $\mathrm{NO}_{\mathrm{x}}$-rich environment, ozone formation is depressed in the immediate pollution source area (due to the NO titration and the "poisonous" $\mathrm{OH}+\mathrm{NO}_{2}$ reaction) until the plume travels a substantial distance to the downwind area. A reduction in $\mathrm{NO}_{\mathrm{x}}$ emissions alleviates or even eases the depression in the immediate downwind area in the $\mathrm{NO}_{\mathrm{x}}$-saturated environment. These suggest that plume evolution history plays an important role in affecting the $\mathrm{NO}_{\mathrm{x}}-\mathrm{VOC}$ sensitivity of $\mathrm{O}_{3}$ formation. The stagnant conditions during this period contribute to the VOC-sensitive chemistry.

Figure 15 shows the peak $\mathrm{O}_{3}$ change for a $50 \%$ reduction in emissions of VOCs and of both $\mathrm{NO}_{\mathrm{x}}$ and VOCs, respectively. In both scenarios, peak $\mathrm{O}_{3}$ concentrations decrease throughout the MCMA, with the former resulting in a larger degree of decrease in peak $\mathrm{O}_{3}$. This result also suggests that
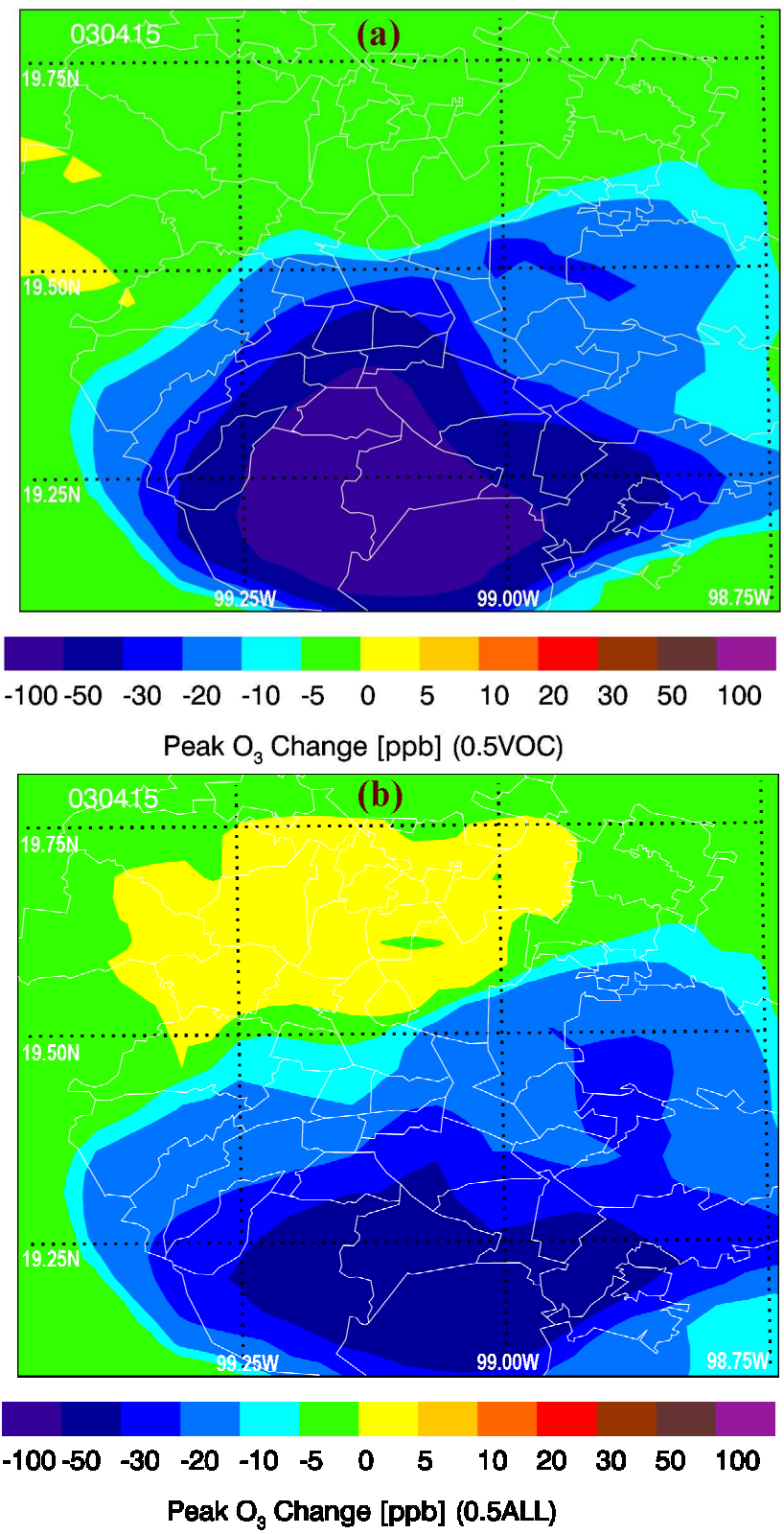

Fig. 15. Change in peak $\mathrm{O}_{3}$ in the model bottom layer on 15 April 2003 due to a $50 \%$ reduction in the emissions of (a) VOCs only and (b) both $\mathrm{NO}_{\mathrm{X}}$ and VOCs.

$\mathrm{O}_{3}$ formation is VOC-sensitive in the MCMA urban region during this episode. The largest decrease in $\mathrm{O}_{3}$ induced by the VOC emission reduction (see Fig. 15a) corresponds to the high $\mathrm{O}_{3}$ area of the reference case. This should be contrasted with the $\mathrm{NO}_{\mathrm{x}}$-only reduction case.

Figure 16 summarizes the responses of near-surface $\mathrm{P}\left(\mathrm{O}_{\mathrm{x}}\right)$ to emissions reductions in $\mathrm{NO}_{\mathrm{x}}$ and $\mathrm{VOC}$ emissions as a function of reference $\mathrm{NO}_{\mathrm{x}}$; modeled data from 12:0017:00 CDT 13-15 April in the urban area analyzed are used. 


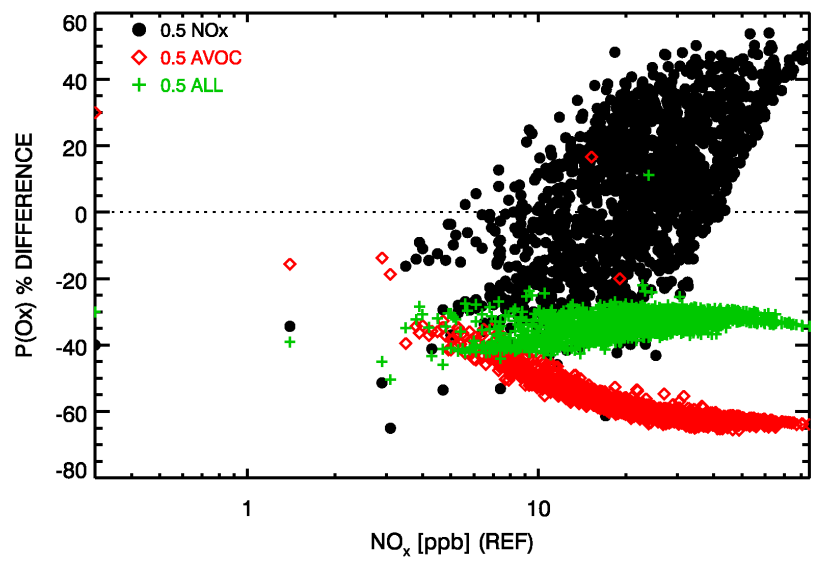

Fig. 16. The Percentage change in $\mathrm{P}\left(\mathrm{O}_{\mathrm{x}}\right)$ as a function of reference $\mathrm{NO}_{\mathrm{x}}$ from 13:00-17:00 CDT during 13-15 April 2003 in the bottom model layer over the "urban analysis area" when emissions of $\mathrm{NO}_{\mathrm{X}}$ and VOC are reduced by $50 \%$ each and when both are reduced.

We present here the response of $\mathrm{P}\left(\mathrm{O}_{\mathrm{x}}\right)$, instead of $\mathrm{O}_{3}$ itself, because the former provides more insights on the chemistry of $\mathrm{O}_{3}$ formation and its relationship with $\mathrm{O}_{3}$ precursors. It shows that under "all" $\mathrm{NO}_{\mathrm{x}}$ conditions sampled (all points with $\mathrm{NO}_{\mathrm{x}}$ concentrations fall in the range shown in the figure), with few exceptions, a reduction in VOC emissions always leads to a decrease in $\mathrm{P}\left(\mathrm{O}_{\mathrm{x}}\right)$, which also changes with $\mathrm{NO}_{\mathrm{x}} .50 \%$ reductions in emissions of both $\mathrm{NO}_{\mathrm{x}}$ and VOC lead to mostly unanimous and constant decreases in $\mathrm{P}\left(\mathrm{O}_{\mathrm{x}}\right)$ over a wide range of $\mathrm{NO}_{\mathrm{x}}$ levels, with the decrease magnitude less than the $\mathrm{NO}_{\mathrm{x}}$-only reduction scenario. Considering the co-emissions of $\mathrm{NO}_{\mathrm{x}}$ and VOCs, it appears that reductions in both VOCs and $\mathrm{NO}_{x}$ are practical to reduce $\mathrm{O}_{3}$ concentrations in MCMA.

The dependence of the $\mathrm{P}\left(\mathrm{O}_{\mathrm{x}}\right)$ change on $\mathrm{NO}_{\mathrm{x}}$ due to the reduction of $\mathrm{NO}_{\mathrm{x}}$ emissions is more complicated. At low $\mathrm{NO}_{\mathrm{x}}$ (less than $\sim 10 \mathrm{ppb}), \mathrm{P}\left(\mathrm{O}_{\mathrm{x}}\right)$ decreases when $\mathrm{NO}_{\mathrm{x}}$ emissions are reduced; at $\mathrm{NO}_{\mathrm{x}}$ levels of $15-30 \mathrm{ppb}$, the reduction of $\mathrm{NO}_{\mathrm{x}}$ emissions can lead to either a decrease or an increase in $\mathrm{P}\left(\mathrm{O}_{\mathrm{x}}\right)$, due to the scattered $\mathrm{P}\left(\mathrm{O}_{\mathrm{x}}\right)-\mathrm{NO}_{\mathrm{x}}$ relationship discussed previously; but at higher levels of $\mathrm{NO}_{\mathrm{x}}(>30 \mathrm{ppb})$, the reduction of $\mathrm{NO}_{\mathrm{x}}$ emissions results in an increase of $\mathrm{P}\left(\mathrm{O}_{\mathrm{x}}\right)$. Despite the scatter of the $\mathrm{P}\left(\mathrm{O}_{\mathrm{x}}\right)$ responses to reductions in $\mathrm{NO}_{\mathrm{x}}$ and VOCs, it appears that VOC emission control is more effective than $\mathrm{NO}_{\mathrm{x}}$ emission control for most $\mathrm{NO}_{\mathrm{x}}$ levels. This conclusion is drawn from Fig. 16, i.e., from the simulated results in the urban area studied and in terms of the $\mathrm{O}_{\mathrm{x}}$ production rate. The conclusion may be different when different regions are targeted. Replacing $\mathrm{P}(\mathrm{Ox})$ with $\mathrm{O}_{3}$, a graph similar to Fig. 16, with a different variability, is obtained. The difference is that $\mathrm{P}\left(\mathrm{O}_{\mathrm{x}}\right)$ may be considered a present state quantity, while $\mathrm{O}_{3}$ not only explicitly includes the influences of physical processes (e.g., transport and deposition), but also carries the history of the air mass (Kleinman, 2000).
These sensitivity calculations are necessarily based on the reference emissions. $\mathrm{O}_{3}$ response to emissions reductions may vary with different base emissions because the $\mathrm{O}_{3}$ sensitivity chemistry can shift from one regime to another. Certainly an accurate EI is a prerequisite to develop an $\mathrm{O}_{3}$ control strategy based on sensitivity studies. In addition, the $\mathrm{O}_{3}$ sensitivity chemistry may vary if the magnitude of emissions reduction changes (e.g., $30 \%$ or $70 \%$ reduction instead of $50 \%$ reduction). Finally, the $\mathrm{O}_{3}$ sensitivity chemistry can behave differently under different meteorological situations, and thus in different regions. Future work will extend the sensitivity analyses to other two meteorological categories that also occur frequently in MCMA, " $\mathrm{O}_{3}$-North" and "Cold Surge", and to improved emission estimates with different perturbations.

\section{Conclusions}

A 3-D chemical transport model (CAMx 4.03) was used to characterize the midday (12:00-17:00 CDT) ozone formation and its response to precursor changes in the MCMA during a 3-day episode of 13-15 April 2003. Model performance was assessed by comparing simulated near-surface $\mathrm{O}_{3}, \mathrm{NO}_{\mathrm{x}}, \mathrm{CO}$, and speciated VOC concentrations with a comprehensive array of measurements at the RAMA monitoring stations and at the CENICA supersite during the MCMA-2003 Campaign. The model successfully reproduces the concentrations of $\mathrm{CO}, \mathrm{NO}_{\mathrm{x}}, \mathrm{O}_{3}$ and VOCs in the MCMA during this episode.

The simulated relationship between $\mathrm{O}_{3}$ production and ambient $\mathrm{NO}_{\mathrm{x}}$ and VOC concentrations is complex and is mainly attributed to the non-homogeneous primary radical sources under different $\mathrm{NO}_{\mathrm{x}}$ levels. The behavior of $\mathrm{P}\left(\mathrm{O}_{\mathrm{x}}\right)$ suggests that $\mathrm{O}_{3}$ formation is VOC-limited during 12:0017:00 CDT in the urban region. The model predicts $\mathrm{O}_{3}$ photochemical formation rates of $10-80 \mathrm{ppb} / \mathrm{h}$ at the most frequently measured $\mathrm{NO}_{\mathrm{x}}$ concentrations. These $\mathrm{NO}_{\mathrm{x}}$ concentrations are much higher than in most U.S. urban regions. The high $\mathrm{O}_{3}$ production is due to the high VOC reactivity in which alkanes, alkenes, and aromatics make comparable contributions. The predicted ozone production efficiency is between 4-10 $\mathrm{O}_{3}$ molecules per $\mathrm{NO}_{\mathrm{x}}$ molecule oxidized, and increases with increasing VOC-to- $\mathrm{NO}_{2}$ reactivity ratio.

Contributions of chemistry, transport, and deposition to $\mathrm{O}_{3}$ production in the boundary layer are apportioned in this study. $\mathrm{O}_{3}$ is produced photochemically during the day, and is transported to the free troposphere via vertical advection in the later afternoon and evening. No significant entrainments from above the PBL occur during morning hours. Deposition has negligible effects on the column ozone within the boundary layer. Significant outflows of pollutants such as $\mathrm{O}_{3}$ and PAN from the urban areas to the surrounding environment are predicted, which can have important influences on the air 
quality on the regional scale. PAN is not in equilibrium during the photochemically active periods.

The response of $\mathrm{O}_{3}$ production to reductions in precursor emissions was investigated using three emissions control scenarios: a $50 \%$ reduction in $\mathrm{NO}_{\mathrm{x}}$ only, a $50 \%$ reduction in VOCs only, and 50\% reductions in both $\mathrm{NO}_{\mathrm{x}}$ and VOCs. $50 \%$ reductions in emissions of VOC-only and in both $\mathrm{NO}_{\mathrm{x}}$ and VOCs lead to decreases in peak $\mathrm{O}_{3}$, with the former reducing $\mathrm{O}_{3}$ most; the latter leads to a constant decrease of $\mathrm{O}_{3}$ production over a wide range of $\mathrm{NO}_{\mathrm{x}}$ levels. A $50 \%$ reduction in $\mathrm{NO}_{\mathrm{x}}$ emissions leads to small decreases, or even increases in peak $\mathrm{O}_{3}$ for less aged $\left(\mathrm{NO}_{\mathrm{z}} / \mathrm{NO}_{\mathrm{y}}<0.3\right)$ urban plumes. These results suggest that $\mathrm{O}_{3}$ formation in the midday during this episode is VOC-sensitive in the urban region, and current $\mathrm{NO}_{\mathrm{x}}$ levels depress the $\mathrm{O}_{3}$ production. Considering the co-emissions of VOCs and $\mathrm{NO}_{\mathrm{x}}$, reductions in both VOCs and $\mathrm{NO}_{\mathrm{x}}$ appear to be practical to lower the $\mathrm{O}_{3}$ levels in MCMA. The sensitivity also evolves with time of the day.

The results obtained from model simulations in this study are based on one meteorological event and one adjusted emission scenario. Because of uncertainties in the emissions inventory and the diverse response of $\mathrm{O}_{3}$ to ambient precursor levels, and the sensitivity of the concentration spatial distribution to meteorology, one episodic simulation may not be sufficient to capture the general features of $\mathrm{O}_{3}-\mathrm{NO}_{\mathrm{x}}-$ VOC chemistry under a specific meteorological condition. More episodic studies are needed to construct a comprehensive and representative picture of the $\mathrm{O}_{3}$ production characteristics in the MCMA and its response to emission controls. Future studies, which are underway, will be performed using upgraded initial emission estimates and more sophisticated emission controls under different meteorological conditions, such as those identified during the MCMA-2003 campaign - the "O $\mathrm{O}_{3}$-North" and "Cold Surge". In addition, it should be noted that the conclusions of this study are applied to the MCMA urban region and may not be applicable to the whole metropolitan area.

Acknowledgements. This research was supported by the Mexican Metropolitan Environmental Commission, the U.S. National Science Foundation (ATM-308748 and 0528227), and the Department of Energy (Award DE-FG02-05ER3980). The authors thank the Secretary of Environment of the Government of the Federal District in Mexico for their contribution in gathering the data used in this manuscript. The authors are grateful to B. Lamb and E. Velasco for providing VOC canister sampling data and $\mathrm{P}$. Sheehy for assistance in DOAS data processing, and to F. San Martini, E. Velasco, B. Lamb, G. Sosa and A. Garcia for their valuable discussions and comments. The authors also acknowledge the constructive comments from the anonymous reviewers, which helped to improve the presentation of this article. CAMx is made publicly available by ENVIRON, and the authors would like to thank G. Yarwood for his support.

Edited by: C. E. Kolb

\section{References}

Arriaga-Colina, J. L., West, J. J., Sosa, G., Escalona, S. S., Ordúñez, R. M., and Cervantes, A. D. M.: Measurements of VOCs in Mexico City (1992-2001) and evaluation of VOCs and CO in the emissions inventory, Atmos. Environ., 38, 2523-2533, 2004.

Baumgardner, D., Raga, G. B., Kok, G., Ogren, J., Rosas, I., Báez, A., and Novakov, T.: On the evolution of aerosol properties at a mountain site above Mexico City, J. Geophys. Res., 105, 22243 $22254,2000$.

CAM (Comisión Ambiental Metropolitana): Inventario de Emisiones 2002 de la Zona Metropolitana del Valle de México, México, 2004.

Carter, W. P. L.: Development of ozone reactivity scales for volatile organic compounds, J. Air Waste Manage. Assoc., 44, 881-899, 1994.

Carter, W. P. L.: Documentation of the SAPRC-99 chemical mechanism for VOC reactivity, final report to California Air Resources Board, Contract 92-329 and 95-308, Calif. Air Res. Board, Sacramento, Calif., 2000.

Carter, W. P. L.: Environmental chamber studies of ozone formation potentials of volatile organic compounds, Proceedings of the NATO Advanced Research Workshop "Environmental Simulation Chambers: Application to Atmospheric Chemical Processes", edited by: Rudzinski, K. and Barnes, I., NATO Sciences Series, IV. Earth and Environmental Sciences, Zakopane, Poland, Kluwer Academic Publishers, 1-4 October 2004.

Castro, T., Madronich, S., Rivale, S., Muhlia, A., and Mar, B.: The influence of aerosols on photochemical smog in Mexico City, Atmos. Environ., 35, 1765-1772, 2001.

Chameides, W. L., Lindsay, R.W., Richardson, J., and Kiang, C. S.: The role of biogenic hydrocarbons in urban photochemical smog - Atlanta as a case-study, Science, 241, 1473-1475, 1988.

Chameides, W. L., Fehsenfeld, F., Rodgers, M. O., et al.: Ozone precursor relationships in the ambient atmosphere, J. Geophys. Res., 97, 6037-6056, 1992.

Chang, J. S., Brost, R. A., Isaksen, I. S. A., Madronich, S., Middleton, P., Stockwell, W. R., and Walcek, C. J.: A three-dimensional Eulerian acid deposition model: Physical concepts and formulation, J. Geophys. Res., 81, 421-423, 1987.

Daum, P. H., Kleinman, L. I., Imre, D. G., Nunnermacker, L. J., Lee, Y.-N., Springston, S. R., Newman, L., and Weinstein-Lloyd, J.: Analysis of the processing of Nashville urban emissions on July 3 and July 18, 1995, J. Geophys. Res., 105, 9155-9164, 2000.

Daum P. H., Kleinman, L. I., Springston, S. R., Nunnermacker, L. J., Lee, Y.- N., Weinstein-Lloyd, J., Zheng, J., and Berkowitz, C. M.: A comparative study of $\mathrm{O}_{3}$ formation in the Houston urban and industrial plumes during the 2000 Texas Air Quality Study: J. Geophys. Res., 108, 4715, doi:10.1029/2003JD003552, 2003.

de Foy, B., Caetano, E., Magana, V., Zitacuaro, A., Cardenas, B., Retama, A., Ramos, R., Molina, L. T., and Molina, M. J.: Mexico City basin wind circulation during the MCMA-2003 field campaign, Atmos. Chem. Phys., 5, 2267-2288, 2005, http://www.atmos-chem-phys.net/5/2267/2005/.

de Foy, B., Clappier, A., Molina, L. T., and Molina, M. J.: Distinct wind convergence patterns due to thermal and momentum forcing of the low level jet into the Mexico City basin, Atmos. Chem. Phys., 6, 1249-1265, 2006a.

de Foy, B., Molina, L. T., and Molina, M. J.: Satellite-derived land surface parameters for mesoscale modeling of the Mexico City 
basin, Atmos. Chem. Phys., 6, 1315-1330, 2006b.

de Foy, B., Lei, W., Zavala, M., Volkamer, R., Samuelsson, J., Mellqvist, J., Galle, B., Martínez, A.-P., Grutter, M., Retama, A., and Molina, L. T.: Modelling constraints on the emission inventory and on vertical dispersion for $\mathrm{CO}$ and $\mathrm{SO} 2$ in the Mexico City Metropolitan Area using Solar FTIR and zenith sky UV spectroscopy, Atmos. Chem. Phys., 7, 781-801, 2007,

http://www.atmos-chem-phys.net/7/781/2007/.

Doran, J. C., Abbott, S., Archuleta, J., Bian, X., Chow, J., Coulter, R. L., de Wekker, S. F. J., Edgerton, S., Elliott, S., Fernandez, A., Fast, J. D., Hubbe, J. M., King, C., Langley, D., Leach, J., Lee, J. T., Martin, T. J., Martinez, D., Martinez, J. L., Mercado, G., Mora, V., Mulhearn, M., Pena, J. L., Petty, R., Porch, W., Russell, C., Salas, R., Shannon, J. D., Shaw, W. J., Sosa, G., Tellier, L., Templeman, B., Watson, J. G., White, R., Whiteman, C. D., and Wolfe, D.: The15 IMADA-AVER boundary layer experiment in the Mexico City area, Bull. Am. Meteorol. Soc., 79, 2497-2508, 1998.

Edgerton, S. A., Bian, X., Doran, J. C., et al.: Particulate Air Pollution in Mexico City: A Collaborative Research Project, J. Air Waste Manage. Assoc., 49, 1221-1229, 1999.

ENVIRON: User's Guide Comprehensive Air Quality Model with Extension (CAMx) Version 4.03. ENVIRON International Coporation, Novato, California, available at: http://www.camx.com, 2003.

Fast, J. D. and Zhong, S.: Meteorological factors associated with inhomogeneous ozoneconcentrations within the Mexico City basin, J. Geophys. Res., 103, 18 927-18 946, 1998.

Finlayson-Pitts, B. J., Wingen, L. M., Summer, A. L., Syomin, D., and Ramazan, K. A.: The heterogeneous hydrolysis of $\mathrm{NO}_{2}$ in laboratory systems and in outdoor and indoor atmospheres: An integrated mechanism, Phys. Chem. Chem. Phys., 5, 223-242, 2003.

Fine, J., Vuilleumier, L., Reynolds, S., Roth, P., and Brown, N., Evaluating uncertainties in regional photochemical air quality modeling, Ann. Rev. Environ. Resour., 28, 59-106, 2003.

Frey, S., Molina, L. T., Molina, M. J., and Wöste, L.: Design and Implementation of a Compact Raman-Lidar for Ozone and Aerosol Measurements, European Space Agency (Special Publication) ESA SP, 1(561), 151-154, 2004.

Gaffney, J. S., Marley. N. A., Cunningham, M. M., and Doskey, P. V.: Measurements of peroxyacyl nitrates (PANS) in Mexico City: implications for megacity air quality impacts on regional scales, Atmos. Environ., 33, 5003-5012, 1999.

Garcia, A. R., Volkamer, R., Molina, L. T., Molina, M. J., Samuelson, J., Mellqvist, J., Galle, B., Herndon, S. C., and Kolb, C. E.: Separation of emitted and photochemical formaldehyde in Mexico City using a statistical analysis and a new pair of gas-phase tracers, Atmos. Chem. Phys., 6, 4545-4557, 2006,

http://www.atmos-chem-phys.net/6/4545/2006/.

Gobierno del Distrito Federal (GDF): Informe del Estado de la Calidad del Aire yTendencias 2003 para la Zona Metropolitana del Valle de México, Dirección Generalde Gestión Ambiental del Aire. México, D.F., 2004.

Grell, G. A., Dudhia, J., and Stauffer, D. R.: A Description of the Fifth-Generation Penn State/NCAR Mesoscale Model (MM5), Tech. Rep. NCAR/TN-398+STR, NCAR, 1995.

IMP (Instituto Mexicano el Petróleo): Investigación sobre materia particulada y deterioro atmosférico, Subdirección de Protección
Ambiental, 1994-1998, 1998.

Jazcilevich, A. D., Garcia, A. D., and Ruiz-Suarez, L. G., A modeling study of air pollution modulation through land-use change in the Valley of Mexico, Atmos. Environ., 36, 2297-2307, 2002.

Jazcilevich, A. D., Garcia, A. D., and Ruiz-Suarez, L. G.: A study of air flow patterns affecting pollutant concentrations in the Central Region of Mexico, Atmos. Environ., 39, 1161-1171, 2003.

Jazcilevich, A. D., Garcia, A. R., and Caetano, E.: Locally induced surface air confluence by complex terrain and its effects on air pollution in the valley of Mexico, Atmos. Environ., 39, 54815489, 2005.

Kleffmann, J., Becker, K. H., and Wiesen, P.: Heterogeneous $\mathrm{NO}_{2}$ conversion processes on acid surfaces: Possible atmospheric implications, Atmos. Environ., 32, 2721-2729, 1998.

Kleinman, L. I.: Ozone process insights from field experiments part II: Observation-based analysis for ozone production, Atmos. Environ., 34, 2023-2033, 2000.

Kleinman, L. I., Daum, P. H., Lee, J. H., Lee, Y.-N., Nunnermacker, L. J., Springston, S. R., Newman, L., Weinstein-Lloyd, J., and Sillman, S.: Dependence of ozone production on NO and hydrocarbons in the troposphere, Geophys. Res. Lett., 24, 2299-2302, 1997.

Kleinman, L. I., Daum, P. H., Imre, D., Lee, Y.-N., Nunnermacker, L. J., Springston, S. R., Weinstein-Lloyd, J., and Rudolph, J.: Ozone production rate and hydrocarbon reactivity in 5 urban areas: A cause of high ozone concentration in Houston, Geophys. Res. Lett., 29(10), 1467, doi:10.1029/2001GL014569, 2002.

Kleinman L. I., Daum, P. H., Lee, Y.-N., Nunnermacker, L. J., Springston, S. R., Weinstein-Lloyd, J., and Rudolph, J.: A comparative study of ozone production in five U.S. metropolitan areas, J. Geophys. Res., 110, D02301, doi:10.1029/2004JD005096, 2005.

Kolb, C. E., Herndon, S. C., McManus, J. B., Shorter, J. H., Zahniser, M. S., Nelson, D. D., Jayne, J. T., Canagaratna, M. R., and Worsnop, D. R.: Mobile laboratory with rapid response instruments for real-time measurements of urban and regional trace gas and particulate distributions and emission source characteristics, Environ. Sci., Technol., 38, 5694-5703, 2004.

LANL/IMP (Los Alamos National Laboratory and Instituto Mexicano del Petróleo): Mexico City Air quality Research Initiative, Los Alamos, NM, 1994.

Lei, W., Zhang, R., Tie, X., and Hess, P.: Chemical characterization of ozone formation in the Houston-Galveston area: A chemical transport model study, J. Geophys. Res., 109, D12301, doi:10.1029/2003JD004219, 2004.

Liu, S. C., Trainer, M., Fehsenfeld, F. C., Parrish, D. D., Williams, E. J., Fahey, D. W., Hubler, G., and Murphy, P. C.: Ozone production in the rural troposphere and the implications for regional and global ozone distributions, J. Geophys. Res., 92, 4191-4207, 1987.

Madronich, S. and Flocke, S.: The role of solar radiation in atmospheric chemistry, in: Handbook of Environmental Chemistry, edited by: Boule, P., pp. 1-26, Springer-Verlag, Heidelberg, Germany, 1998.

Marley, N. A., Gaffney, J. S., White, R. V., Rodriguez-Cuadra, L., Herndon, S. E., Dunlea, E., Volkamer, R. M., Molina, L. T., and Molina, M. J.: Fast gas chromatography with luminol chemiluminescence detection for the simultaneous determination of nitrogen dioxide and peroxyacetyl nitrate in the atmosphere, Rev. 
Sci. Instrum. 75, 4595-4605, 2004.

Molina, L. T. and Molina, M. J. (Eds.): Air Quality in the Mexico Megacity: An integrated Assessment, Kluwer Academic Publishers, 2002.

Molina, M. J. and Molina, L. T.: Megacities and Atmospheric Pollution, J. Air Manage. Assoc., 54, 644-680, 2004.

Molina, L. T., Molina, M. J., Slott, R. S., Kolb, C. E., Gbor, P. K., Meng, F., Singh, R. B., Galvez, O., Sloan, J. J., Anderson, W. P., Tang, X. Y., Hu, M., Xie, S., Shao, M., Zhu, T., Zhang, Y. H., Gurjar, B. R., Artaxo, P. E., Oyola, P., Gramsch, E., Hidalgo, D., and Gertler, A. W.: 2004 Critical Review online version: Air Quality in Selected Megacities, http://www.awma.org, 2004.

Nunnermacker, L. J., Imre, D., Daum, P. H., Kleinman, L., Lee, Y.N., Lee, J. H., Springston, S. R., Newman, L., Weinstein-Lloyd, J., Luke, W. T., Banta, R., Alvarez, R., Senff, C., Sillman, S., Holdren, M., Keigley, G. W., and Zhou, X.: Characterization of the Nashville urban plume on July 3 and July 18, 1995, J. Geophys. Res., 103, 28 129-28 148, 1998.

O'Brien, J. J.: A note on the vertical structure of the eddy exchange coefficient in the planetary boundary layer, J. Atmos. Sci., 27, 1214-1215, 1970.

Odum, J. R., Hoffmann, T., Bowman, F., Collins, D., Flagan, R. C., and Seinfeld, J. H.: Gas/Particle Partitioning and Secondary Organic Aerosol Yields, Environ. Sci. Technol., 30, 2580-2585, 1996.

Raga,G. B., Baumgardnera, D., Castroa, T., Martínez-Arroyoa, A., and Navarro-González, R.: Mexico City air quality: a qualitative review of gas and aerosol measurements (1960-2000), Atmos. Environ., 35, 4041-4058, 2001.

Rogers, T. M., Grimsruda, E. P., Herndon, S. C., et al.: On-road measurements of volatile organic compounds in the Mexico City Metropolitan Area using proton transfer reaction mass spectrometry, International J. Mass Spectrom., 252(1), 26-37, 2006.

Russell, A. and Dennis, R.: NARSTO critical review of photochemical models and modeling, Atmos. Environ., 34, 2283-2324, 2000.

Salcedo, D., Onasch, T. B., Dzepina, K., et al.: Characterization of ambient aerosols in Mexico City during the MCMA-2003 campaign with Aerosol Mass Spectrometry: results from the CENICA supersite, Atmos. Chem. Phys., 6, 925-946, 2006, http://www.atmos-chem-phys.net/6/925/2006/.

Salcedo, D., Onasch, T. B., Canagaratna, M. R., et al.: Technical Note: Use of a beam width probe in an Aerosol Mass Spectrometer to monitor particle collection efficiency in the field, Atmos. Chem. Phys., 7, 549-556, 2007, http://www.atmos-chem-phys.net/7/549/2007/.

Seinfeld, J. H. and Pandis, S. N.: Atmospheric Chemistry and Physics: From Air Pollution to Climate Change, John Wiley Sons, New York, 1998.

Shirley, T. R., Brune, W. H., Ren, X., Mao, J., Lesher, R., Cardenas, B., Volkamer, R., Molina, L. T., Molina, M. J., Lamb, B., Velasco, E., Jobson, T., and Alexander, M.: Atmospheric oxidation in the Mexico City Metropolitan Area (MCMA) during April 2003, Atmos. Chem. Phys., 6, 2753-2765, 2006, http://www.atmos-chem-phys.net/6/2753/2006/

Sillman, S., Logan, J. A., and Wofsy, S. C.: The sensitivity of ozone to nitrogen oxides and hydrocarbons in regional ozone episodes, J. Geophys. Res., 95, 1837-1851, 1990.

Sillman, S.: The use of $\mathrm{NO}_{\mathrm{y}}, \mathrm{H}_{2} \mathrm{O}_{2}$, and $\mathrm{HNO}_{3}$ as indicators for ozone- $\mathrm{NO}_{\mathrm{x}}$-hydrocarbon sensitivity in urban locations, J. Geophys. Res., 100, 14 175-14 188, 1995.

Sillman, S.: The relation between ozone, $\mathrm{NO}_{\mathrm{x}}$ and hydrocarbons in urban and polluted rural environments, Atmos. Environ., 33, $1821-1845,1999$.

Simeonov, V., Ristori, P., Taslakov, M., van den Bergh, H., Molina, L. T., and Molina, M. J.: Ozone and Aerosol Distribution Measured Above Mexico City with a Differential Absorption Lidar during the MCMA 2003 Field Campaign, in: Proceedings of the XX Quadrennial Ozone Symposium, Kos Greece, vol. 1 pp. 435437, 1-8 June 2004

St. John, J. C., Chameides, W. L., and Saylor, R.: Role of anthropogenic $\mathrm{NO}_{\mathrm{x}}$ and VOC as ozone precursors: A case study from the SOS Nashville/Middle Tennessee Ozone Study, J. Geophys. Res., 103, 22 415-22 424, 1998.

Streit, G. E. and Guzmán, F.: Mexico City Air quality: Progress of an international collaborative project to define air quality management options, Atmos. Environ., 30, 723-733, 1996.

Stutz, J., Alicke, B., Ackermann, R., Geyer, A., Wang, S., White, A B., Williams, E. J., Spicer, C. W., and Fast, J. D.: Relative humidity dependence of HONO chemistry in urban areas, J. Geophys. Res., 109, D03307, doi:10.1029/2003JD004135, 2004.

Tonnesen, G. S. and Dennis, R. L.: Analysis of radical propagation efficiency to assess ozone sensitivity to hydrocarbons and $\mathrm{NO}_{\mathrm{x}}$. 1. Local indicators of instantaneous odd oxygen production sensitivity, J. Geophys. Res., 105, 9213-9226, 2000.

Velasco, E., Lamb, B., Pressley, S., Allwine, E., Westberg, H., Jobson, T., Alexander, M., Prazeller, P., Molina, L., and Molina, M.: Flux measurements of volatile organic compounds from an urban landscape, Geophys. Res. Lett., 32, L20802, doi:10.1029/2005GL023356, 2005.

Velasco, E., Lamb, B., Westberg, H., Allwine, E., Sosa, G., Arriaga, J. L., Jonson, T., Alexander, M., Prazeller, P., Knighton, B., Rogers, T. M., Grutter, M., Herndon, S. C., Kolb, C. E., Zavala, M., de Foy, B., Molina, L. T., and Molina, M. J.: Distribution, magnitudes, reactivities, ratios and diurnal patterns of volatile organic compounds in the Valley of Mexico during the MCMA 2002 \& 2003 field campaigns, Atmos. Chem. Phys., 7, 329-353, 2007, http://www.atmos-chem-phys.net/7/329/2007/.

Volkamer, R., Molina, L. T., Molina, M. J., Shirley, T., and Brune, W. H.: DOAS measurement of glyoxal as an indicator for fast VOC chemistry in urban air, Geophys. Res. Lett., 32, L08806, doi:10.1029/2005GL022616, 2005.

West, J. J., Zavala, M. A., Molina, L. T., Molina, M. J., San Martini, F., McRae, G. J., Sosa-Iglesias, G., and Arriaga-Colina: J. L.: Modeling ozone photochemistry and evaluation of hydrocarbon emissions in the Mexico City metropolitan area, J. Geophys. Res., 109, D19312, doi:10.1029/2004JD004614, 2004.

Whiteman, C. D., Zhong, S., Bian, X., Fast, J. D., and Doran, J. C.: Boundary layer evolution andregional-scale diurnal circulations over the Mexico Basin and Mexican Plateau, J. Geophys.Res. 105, 10 081-10 102, 2000

Williams, M. D., Brown, M. J., Cruz, X., Sosa, G., and Streit, G.: Development and testing of meteorology and air dispersion models for Mexico City, Atmos. Environ., 29, 2929-2960, 1995.

Young, A. T., Betterton, E. A., and Salvidar de Rueda, L.: Photochemial bos model for Mexico City, Atmosfera, 10, 161-178, 1997. 
Zavala, M., Slott, R., S, Dunlea, E. J., Marr, L., Molina, L. T., Molina, M. J., Herndon, S. C., Shorter, J. H., Zahniser, M., Kolb, C. E., Knighton, B., and Rogers, T: Characterization of on-road vehicle emissions in the Mexico City Metropolitan Area using a mobile laboratory in chase and fleet average measurement modes during the MCMA-2003 field campaign, Atmos. Chem. Phys., 6, 5129-5142, 2006,

http://www.atmos-chem-phys.net/6/5129/2006/. 